\title{
Sedimentary and Geochemical Aspects of a Refinery Impacted Coastal Area: A Case Study of the Todos os Santos Bay (Bahia, Brazil)
}

\author{
Roberto L. Barcellos $^{1 *}$, Elisabete S. Braga², Valdenir V. Furtado², Glaucia B. B. Berbel² \\ ${ }^{1}$ Department of Oceanography, Federal University of Pernambuco, Recife, Brazil \\ ${ }^{2}$ Institute of Oceanography, University of São Paulo, São Paulo, Brazil \\ Email: roberto.barcellos@ufpe.br, edsbraga@usp.br, vfurtado@usp.br, glauciaberbel@uol.com.br
}

Received 18 September 2014; revised 13 October 2014; accepted 5 November 2014

Copyright (C) 2014 by authors and Scientific Research Publishing Inc.

This work is licensed under the Creative Commons Attribution International License (CC BY). http://creativecommons.org/licenses/by/4.0/

(c) (i) 0 pen Access

\begin{abstract}
The present study was performed in the northeast portion of the Todosos Santos Bay, Bahia State, Brazil, an area under influence of the Landulpho Alves-Mataripe (RLAM) refinery effluents. The aim of this work is to evaluate the modern sedimentary processes based on grain-size analysis, calcium carbonate and sedimentary organic matter concentration and behavior considering the possible effects of the petroleum industry's refining on these sediments. The concentrations and variations of the three main constituents of organic matter (total organic $\mathrm{C}$, total $\mathrm{N}$ and organic $\mathrm{P}$ ), and the resulting elemental ratios (C/N, C/P and N/P), were studied on a seasonal spatial and temporal scale (winter 2004 and summer 2005), therefore subsidizing the environmental analysis, especially in regards to the benthic ecosystem. Fifty samples from twenty-five sampling stations were collected with a grab sampler. Well sorted sandy sediments are observed in coastal sampling stations and in the Caboto channel. The recent deposition of fine sediments was observed especially in the west and central portions of study area. However, these spots contain the highest percentages of organic material, which do not present significant seasonal and spatial variations, revealed by the values of total organic $C$ which reach values of up to $3.1 \%$, total $N(0.01 \%$ to $0.15 \%)$ and the organic $P$ contents that reach a maximum of $15.9 \mu \mathrm{mol} \cdot \mathrm{g}^{-1}$. In general, the elemental ratios indicated continental organic matter inputs, probably derived from human activities.
\end{abstract}

\section{Keywords}

Coastal Bay Sediments, Sedimentary Organic Matter, Seasonality, Petroleum Refinery Pollution,

${ }^{*}$ Corresponding author.

How to cite this paper: Barcellos, R.L., Braga, E.S., Furtado, V.V. and Berbel, G.B.B. (2014) Sedimentary and Geochemical Aspects of a Refinery Impacted Coastal Area: A Case Study of the Todos os Santos Bay (Bahia, Brazil). International Journal of Geosciences, 5, 1451-1467. http://dx.doi.org/10.4236/ijg.2014.512119 


\section{Brazilian Tropical South Atlantic}

\section{Introduction}

The sediments accumulate in restricted areas on the surface of the earth, where well defined physical, chemical and biological processes occur, leading to the formation of a sedimentary formation [1]. These areas are called sedimentation environments. A sedimentary formation is, therefore, the result of a process where there is the interaction of different factors. This formation may hold, within itself, records of these processes, providing information on the origin of the material, means of transport and characteristics of the deposition environment [2]. The study of sediments is therefore a fundamental subsidy for the comprehension of environments and of the ecological relations within, as well as for the establishment of evolutionary models for quaternary sedimentation [3]. It has been increasingly used in studies of quality evaluation of aquatic ecosystems for it is considered to be an integrating site which presents the ability of stocking nutrients and other organic substances, making these chemical species available to the aquatic biota and water column [4].

The grain-size of the deposited sediments is indicative of the energy on the bottom. The occurrence of pelitic deposits (silts and clay), for example, is associated to areas of low energy, with restricted bottom movement and with a seaward transport carried out essentially in suspension. These fine deposits are associated to higher percentages of chemical elements dissolved in water. The pelits, especially clays, by means of adsorption and retention in interstitial water, have the capacity of concentrating these elements (Trask, 1939 apud [2]). The absence of movement on the bottom, in areas of deposition, encumbers the removal of the pelits. Abnormally high values in a given area may be seen as evidence of anthropic contribution. The discharge of rivers is the main means of input of these elements. The psamites sediments (grain and sand) are due to the proximity of the current source (crystalline), to past processes (relict sediments) or to the fragmentation of carbon edifications (biodebris).

The carbonates, in coastal environments, are the result of the accumulation of the shells of organisms, especially mollusks, forming bioclastic deposits or, as in the present case, are the result of active organism action forming banks, or reefs, of calcareous algae and corals. These carbon formations need warm and transparent waters for their formation. The percentage of carbonate therefore indicates the presence of these formations and of deposits derived from their erosion.

The sediments correspond to an active interface of the hydrous system, with a strong influence on local biogeochemical cycles. They are involved in the temporary removal/addition of many anthropic and natural compounds. Sediments may be re-suspended and distributed by wave and current action [5] [6]. This process acts on superficial sediments which contain recently deposited organic material. In shallow waters, the deposited material may be rich in easily degradable fractions, such as detritus from dead marine organisms which rapidly reach the superficial sediment, as well as other detritus with more refractory characteristics, typical of terrestrial input. In the sediment, many remineralization processes may occur, which reflect on the carbon, nitrogen, and phosphate contents.

The sediments cover almost the entire ocean floor. Their physical characteristics, as well as their composition and bottom sediment distribution, provide indications of depositional areas and the input of sediments to the marine environment. Associated to the information on local hydrodynamics, the physical-chemical behavior and the biological characteristics of the area may lead to a better understanding of the dynamics and the natural tendencies of the studied environment, propitiating a more complete environmental analysis. As a result of this analysis, subsidies for better planning on the adequate use of environments may be obtained. These considerations become even more important in the case of coastal zones, where there are both continental and marine factors involved [7].

The $\mathrm{C} / \mathrm{N}$ and $\mathrm{C} / \mathrm{P}$ ratios may also contribute to the study of the origin of organic matter associated to the sediment. In the case of $\mathrm{C} / \mathrm{P}$, values between 7 and 80 reflect sediments with intense bacterial activity; from 80 to 300 reflect marine or mixed origin; above 300 reflect continental input (vegetal tissue and others) [8]. As to the $\mathrm{C} / \mathrm{N}$ ratio, values between 4 and 6 are attributed to intense bacterial activity, from 4 to 7 as deriving from plankton and benthos (marine origin); above 20 to continental origin and values from 8 to 12 are interpreted as a mixture of marine plankton and terrestrial plants (mixed origin) [8]-[11]. In regards to the N/P proportion, the predicted values for sea water are from 15 to 16 [12], with an increase in coastal regions.

The knowledge of sediment composition is important in order to recognize the toxic signs in benthic organ- 
isms and the diffusion to the biota. The contents of organic carbon, organic phosphorous and total nitrogen are related to the organic matter and may show indications of eutrophication and provide important information on anthropic action and the origin of the material deposited on the sediments. The content of the organic material also evidences the dynamics and the proportion between assimilation/decomposition, which reflects the degree of deterioration of a given system. The grain-size distributions of carbonate concentration and of the characteristics of organic matter are, therefore, indicative of environmental characteristics providing subsidy for a better understanding of the system.

The aim of the present study is mainly to evaluate the presence of preferential areas of input and deposition of sediments in the northeast portion of the Todos os Santos Bay (Bahia State, Brazil), adjacent to the area under influence of the Landulpho Alves-Mataripe (RLAM) refinery. This is done based on grain-size analysis and percentages of calcium carbonate and retention of chemical elements and organic material.

With the purpose of evaluating the resulting effects of the petroleum industry's refining on these sediments, the concentrations and variations of the three main constituents of organic matter (total organic carbon, total nitrogen and organic phosphorus) were studied on a seasonal spatial and temporal scale (winter 2004 and summer 2005), therefore subsidizing the environmental analysis, especially in regards to the benthic ecosystem.

\section{Study Area}

The Todos os Santos Bay is the largest bay on the Brazilian coast, with an area of approximately $927 \mathrm{~km}^{2}$ and 56 islands, as well as the most navigable. It is characterized as a vast region dominated by the flow of tides, with the greatest depths in its central portion and presenting a constriction in its communication with the ocean between the island of Itaparica and the city of Salvador (BA). The meso-tidal regime (2.8 $\mathrm{m}$ in the spring tides) is the main factor in determining the hydrodynamic circulation in the bay, characterized by flooding currents in the NE direction and ebbing currents in the SW direction [13]. The climate is tropical, with a marked rainy season (April to June). During the summer, the SE winds are predominant, while in the winter the NE winds prevail [14].

Since 1950, the Todos os Santos Bay has suffered impacts associated to the growing industrialization of the surrounding area and to the exploitation of its natural resources [15]. Around the Bay is the largest city of the northeast region, Salvador, with approximately 2.7 million habitants ( $1^{\text {st }}$ in Northeast Region) aside from the 10 towns situated in the metropolitan region adding up to a total of 3.6 million habitants ( $7^{\text {th }}$ in the country) [16]. Currently, effluents of 29 industries are dumped directly into the bay contributing, together with urban and port activities, with the pollution of several areas of the bay.

The study area is located between the latitude $12^{\circ} 42^{\prime}-12^{\circ} 45^{\prime}(\mathrm{S})$ and longitude $38^{\circ} 32^{\prime}-38^{\circ} 36^{\prime}(\mathrm{W})$ coordinates, in the northeast portion of the Todos os Santos bay, Bahia State Brazil (Figure 1). It is an area of shallow depths, which vary from 0.5 to $1.0 \mathrm{~m}$, subject to the influence of the discharge of three rivers that flow through mangroves and carry particles of industrial and urban origin: the Caípe River, the Mataripe River and the São Paulo River. A petroleum refinery belonging to PETROBRÁS, the "Landulpho Alves-Mataripe Refinery" (RLAM) and the "Marine Terminal Madre de Deus" (TEMADRE) are situated in the adjacency of the study area where their effluents are also dumped [13].

\section{Material and Methods}

In the sampling cruises carried out in July/August of 2004 (Winter cruise) and January 2005 (Summer cruise) 50 samples of sediment were collected for grain-size analysis, percentage of calcium carbonate and for the study of the main constituents of organic matter (total organic carbon, total nitrogen and organic phosphate) using a Van Veen bottom sampler, with a sampling area of $0.05 \mathrm{~m}^{2}$ in 25 stations within RLAM's area of influence. The controlling of the position, the location of the sampling stations and the depths were obtained by a GPS and the vessel's Echo Sounder.

The samples were taking at each station in triplicates of about $50 \mathrm{~g}$ of sediment were collected and packed in plastic bags duly labeled and chilled until their arrival at the field laboratory where they were transferred to the freezer $\left(-20^{\circ} \mathrm{C}\right)$. The frozen samples were sent to the Laboratories of Sediments, Nutrients, micronutrients and trace elements in the ocean (LABNUT) at the Oceanographic Institute of the University of São Paulo where they were processed.

The samples were analyzed, as to grain-size, by the method of sieving and pipetting, as described by Refer- 


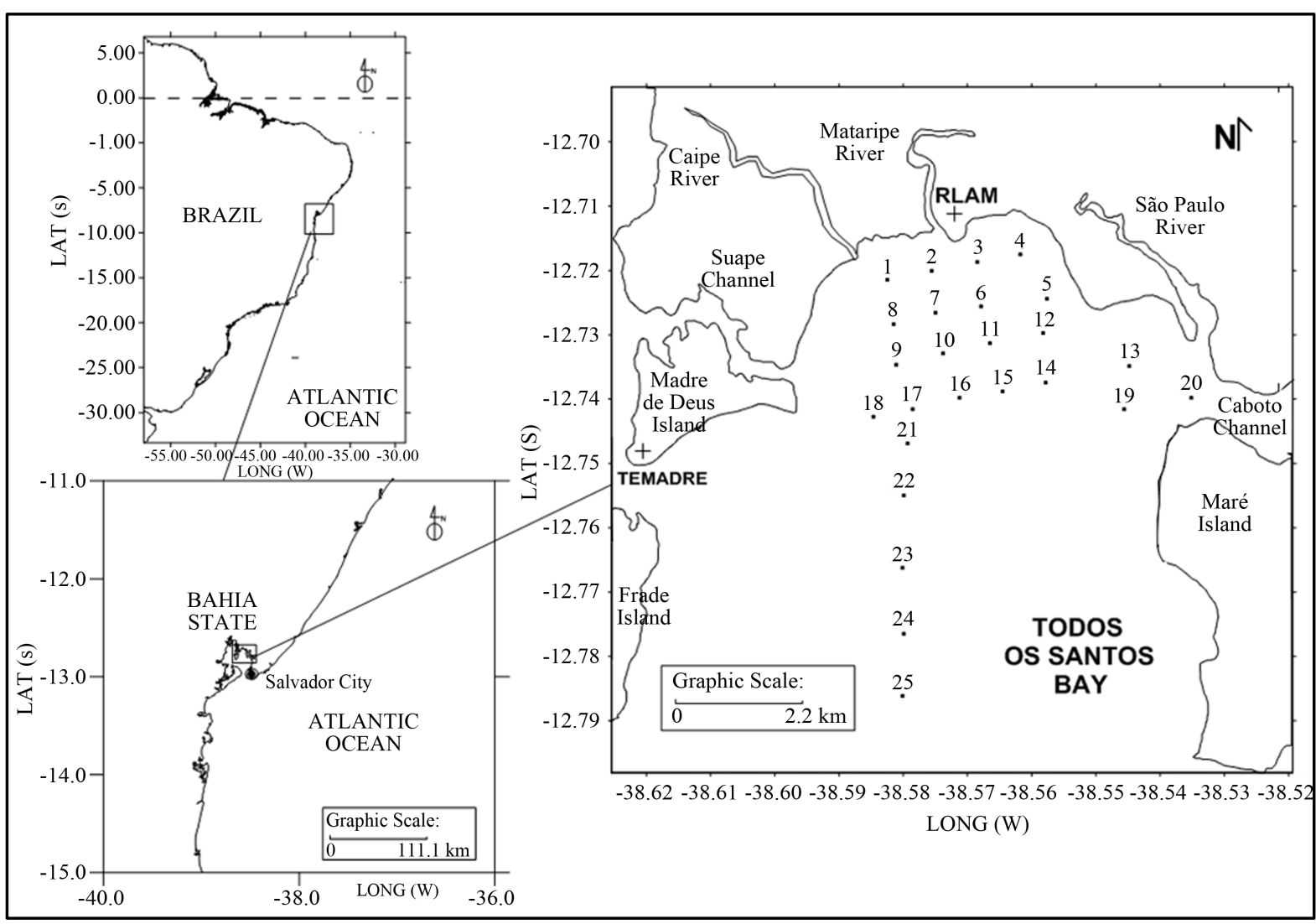

Figure 1. Study area and sampling stations location.

ence [17]. The carbonates were not eliminated from the sample for the grain-size analysis. The percentages of carbonates were obtained by acid dissolution, with $\mathrm{HCl}$ at $10 \%$ and the difference between initial and final weight of the sample after dissolution [18]. The classification was done according to Reference [19].

The sediment samples collected in triplicates were gathered in a sole compound sample, per station, for the chemical analysis. The analysis methods are described for each variable.

The organic carbon (org C) was determined in a sample of $0.5000 \mathrm{~g}$ weighed on a precision analytic scale with a precision of $\pm 0.0001 \mathrm{~g}$ which was subject to an oxidation process with potassium dichromate, according to the recommendations of Reference [20]. This process consists basically of adding dichromate and sulphuric acid to the sediment sample. After agitation, followed by a period of rest, phosphoric acid and soduim fluorite were added, using diphenilamine as an indicator. Following, a titration with a solution of iron II sulphate and ammonium was carried out.

The determination of organic phosphorus (OP) was done in a $0.5000 \mathrm{~g}$ fraction of sediment subject to ignition, a process which followed the recommendation of Reference [21].

The total nitrogen (NT) was extracted from a $0.2000 \mathrm{~g}$ sample of sediment by strongly alkaline solutions with sodium persulphate and then oxidized to nitrate and analyzed in accordance with the recommendations of Reference [22].

The standard sediments used were LECO ${ }^{\circledR}$ SOIL, for total nitrogen and organic carbon, and NIST 2709 for organic phosphorus.

\section{Data Treatment}

The grain-size analysis data obtained were treated with the statistics parameters applied by Reference [23], the textural classification by Reference [24], and the percentages of gravel, sand, silt and clay. The results were organized in tables with an EXCEL ${ }^{\circledR} 7.0$ spreadsheet and the obtained data were mapped using a system of geographic information (SURFER ${ }^{\circledR} 11.0$ ), generating distribution maps for various parameters. A matrix containing 
grain-size data and studied organic matter components was put together, which served as a basis for the correlation analysis among variables. The chosen correlation coefficient was Spearman's non-parametric coefficient [25] due to the abnormal nature of the data, taking into account a 0.05 significance level. The statistical program used was the Statistical Program for Social Science-version 13 (SPSS13 $\left.{ }^{\circledR}\right)$. The data were also treated by applying statistical correlation techniques and grouping by clusters using the Bray-Curtis method, version $3.1\left(\right.$ MVSP $\left.^{\circledR}\right)$.

\section{Results}

\subsection{Grain-Size Analysis and Percentages of Carbonates}

The results obtained in the August 2004 and January 2005 sampling cruises were described in terms of grainsize analysis and carbonates contents. In the winter samples (August 2004), one may observe the occurrence of a percentage of $32 \%$ of psamitic sediments and $68 \%$ of pelitic sediments, in the submerse area under direct influence of the RLAM. The sands are dominant in the psamites (87.5\%) and the clays ( 94\%) are dominant in the pelits. The samples are, for the most part (68\%), lithoclastic, that is, with less than $30 \%$ of carbonates, according to the classification of Reference [19]. Four samples present percentages above $50 \%$ of carbonates (samples 5, 6, 12 and 14) (biolithoclastic and bioclastic) and another four (8, 9, 24 and 25) present percentages over 30\% (lithobioclastics).

In the summer samples (January 2005), there is a percentage of $36 \%$ of psamitic sediments (with a predominance of $77.8 \%$ sands) and $64 \%$ of pelitic sediments (with a predominance of $93.3 \%$ clays). The samples, as in the previous sampling cruise, are predominantly lithoclastics (84\% of the samples). Samples 5, 6, 12 and 14 have percentages over $50 \%$ and are both lithobioclastics and bioclastic.

Figure 2 and Figure 3 illustrate the mean diameter distributions (Folk \& Ward, 1957) (Figure 2(a) and Figure 2(b)), sorting (Folk \& Ward, 1957) (Figure 2(c) and Figure 2(d)), percentage of sand (Figures 3(a) and Figure 3(b)) and percentage of clay (Figures 3(c) and Figure 3(d)) for samples collected during both campaigns. The scale, in phi, used for grain-size, is based on the Wentworth Classification, (Wentworth, 1922 apud [26]).

The analysis of the sedimentary distribution shows a predominance of fine and very fine sandy sediments, moderately sorted to very well sorted and sediments with sand percentages over $75 \%$ from the center-east portion of the bay to the coastline, especially from the Mataripe River to the west portion (Suape Channel). The northeast region is an exception where one may observe the occurrence of medium silt on the coast.

On the center-south portion of the bay there is an increase in fine sediments with sand percentages below $50 \%$. The central portion is dominated by very fine silt and a bathymetric depression $(>10 \mathrm{~m})$ with clay contents over $45 \%$ may be observed. Silt sediments also occur in the eastern portion of the area. To the southwest, east and in the central portion of the area there is a significant decrease in sediment sorting (sample 8, Figure 2(c)), as well as to the east of sample 5 . In the east-southeast portion the sediments are also poorly sorted, with clay contents over $30 \%$.

There is, however, an uncertainty as to the south-southeast area for no samples were collected to the east of the complementary transect.

Figure 4(a) and Figure 4(b) illustrate the carbonate contents of the samples. There is a predominance of lithoclastic sediments $\left(<30 \%\right.$ of $\left.\mathrm{CaCO}_{3}[19]\right)$ in the area which extends over the entire coast from east-southwest to southeast. Bioclastic sediments $(>50 \%)$ are located on the central to east-southwest portion of the area and, in isolated samples in the center-west and east, the sediment is lithobiclastic (between $30 \%$ and $50 \%$ ). The carbonate, which represents a secondary contribution to the sediments, presents more significant variations between campaigns due to its variable sources.

\subsection{Sediment Geochemistry}

The organic carbon (org C) varied between $0.06 \%$ and 2.89\% in the winter of 2004 (Figure 5(a)) with an average of $1.36 \% \pm 0.82 \%$ and a predominance of percentages between $1.0 \%$ and $2.0 \%$. The stations with the highest contents ( $>2.0 \%$ ) were stations $7,9,10,11$ and 18 , situated where the pelitic (silt and clay) sediments predominate. The lowest percentages (below $0.5 \%$ ) were observed in the stations near the coast (1, 2 and 3), composed by essentially sandy quartz sediments as well as in stations 6,12 and 14 , rich in calcium carbonate ( $>95 \%$ ). The organic carbon in the summer of 2005 (Figure 5(b)) varied between $0.09 \%$ and 3.09\%, with an 


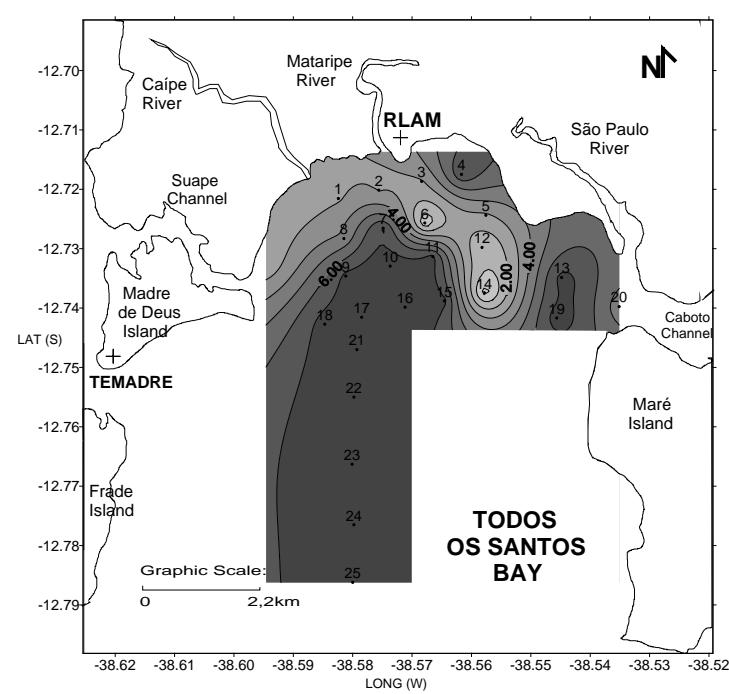

(a)

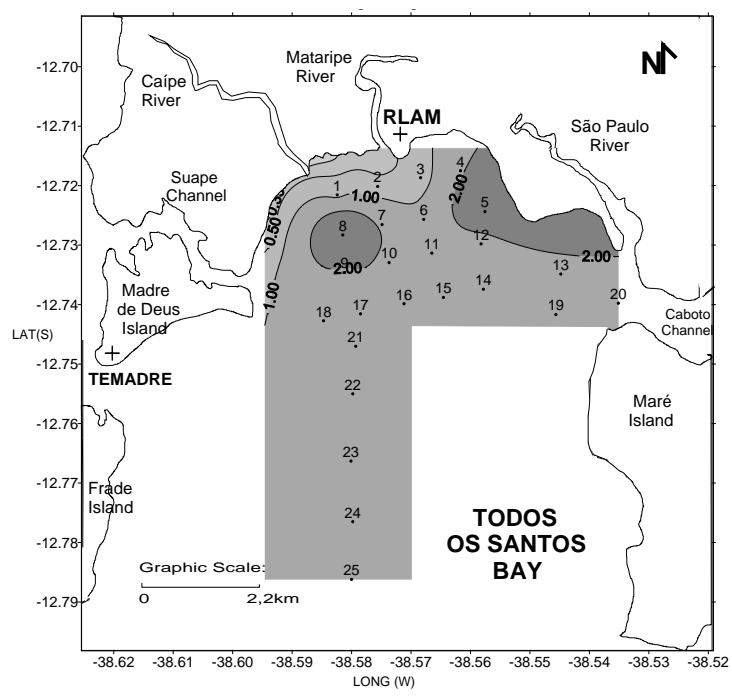

(c)

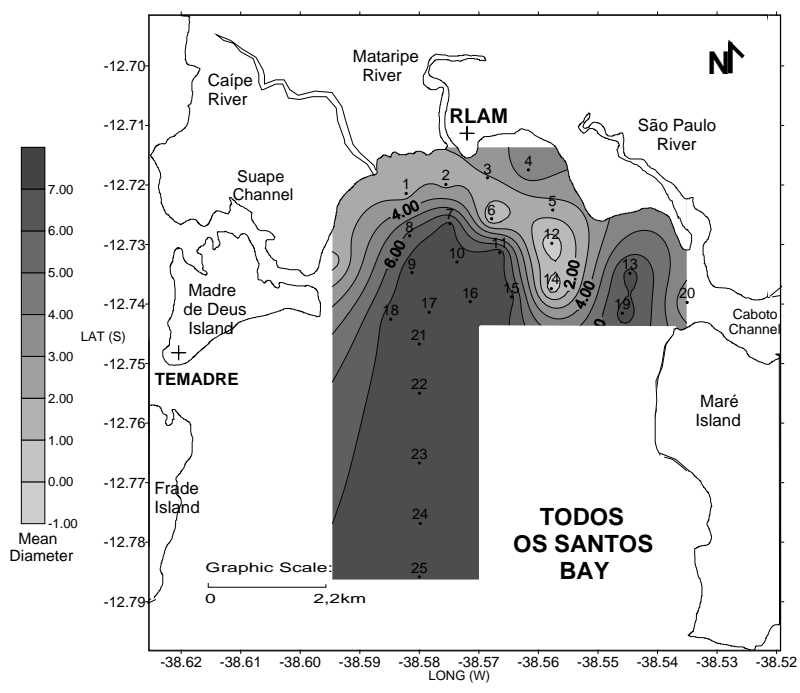

(b)

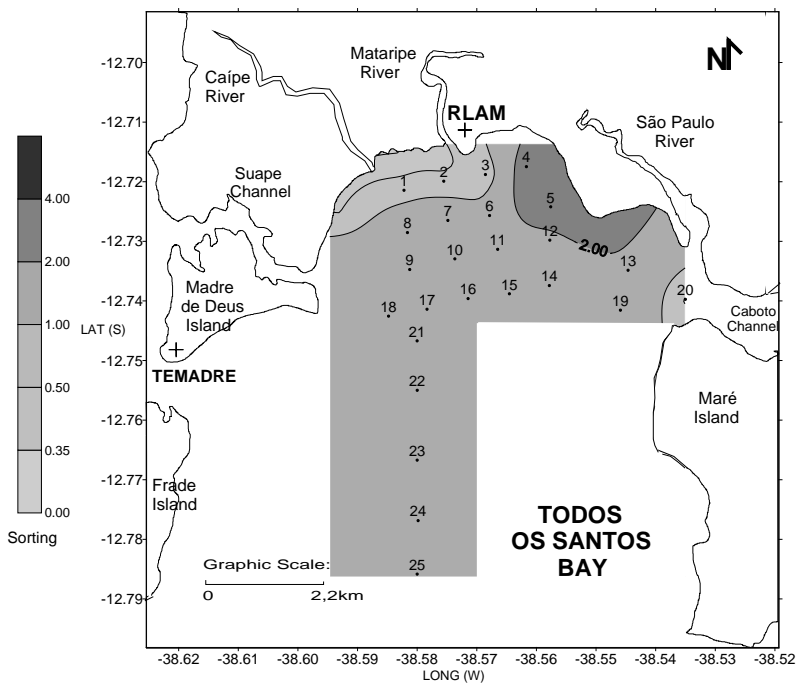

(d)

Figure 2. Mean Diamater in winter (a) and summer (b) and sorting in winter (c) and in summer of sediment sampling stations.

average of $1.25 \% \pm 0.83 \%$ and a predominance of percentages between $0.5 \%$ and $1.5 \%$. The stations which presented higher contents, above $2.0 \%$ (7, 8, 9 and 11), are located in the same area observed during summer, where the finer sediments prevail. Percentages below $0.5 \%$ are associated to lithoclasticsandy sediments near the coast (stations 1, 2 and 3) and on the Caboto Channel (station 20), as well as in station 6, characterized by bioclastic sediments $\left(93.8 \%\right.$ of $\left.\mathrm{CaCO}_{3}\right)$.

The values of total nitrogen in the winter of 2004 (Figure 6(a)) oscillated between $0.01 \%$ and $0.15 \%$, with an average of $0.09 \% \pm 0.04 \%$. A predominance of contents between $0.01 \%$ and $0.15 \%$ were observed, which are considered as high (above $0.10 \%$ ) according to Reference [27]. The stations with higher contents (4, 7, 8, 9, 10, $11,15,16,17,18,19,21,22$ and 23) are generally composed by lithoclastic sediments with high percentages of clay $(>42.7 \%)$. Lower values $(<0.05 \%)$ are associated to lithoclastic sandy sediments located near the coast (stations 1, 2 and 3), on the Caboto Channel (station 20) and in samples with very high percentages of carbonates (stations 6, 12 and 14), which is in agreement with the tendency observed for the organic carbon distribution. The total nitrogen values in the summer of 2005 (Figure 6(b)) present a uniform distribution, oscillating from $0.02 \%$ to $0.14 \%$, with an average of $0.10 \% \pm 0.04 \%$, with a predominance of contents between $0.10 \%$ and 


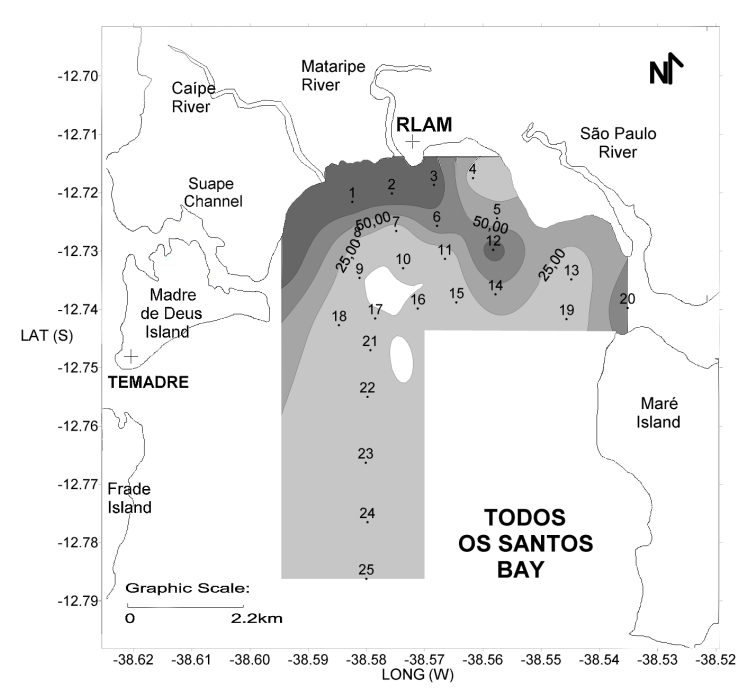

(a)

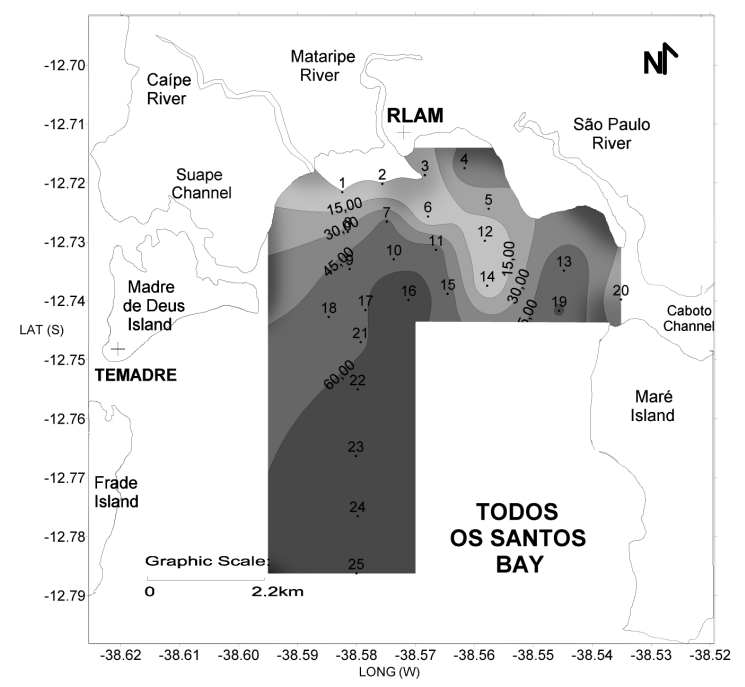

(c)

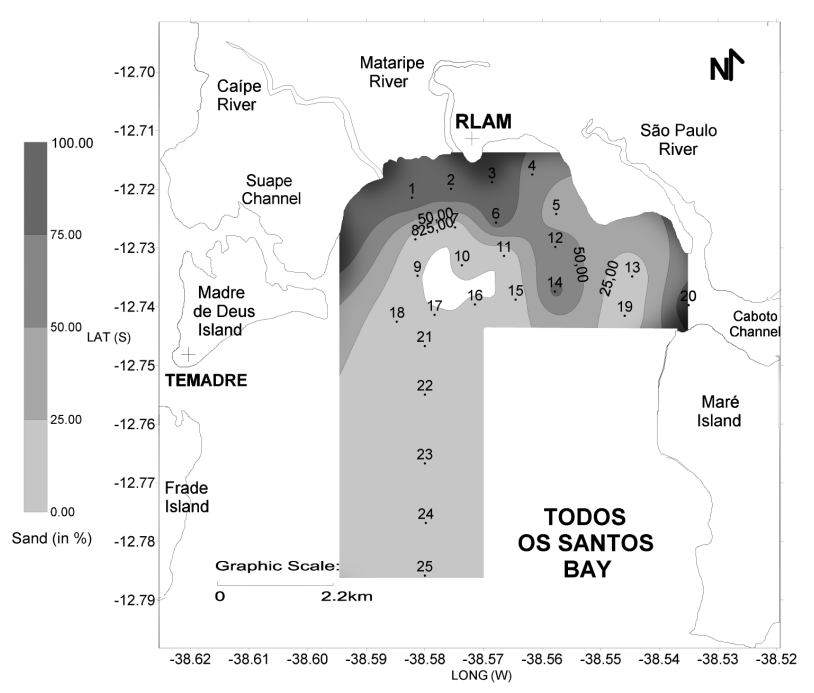

(b)

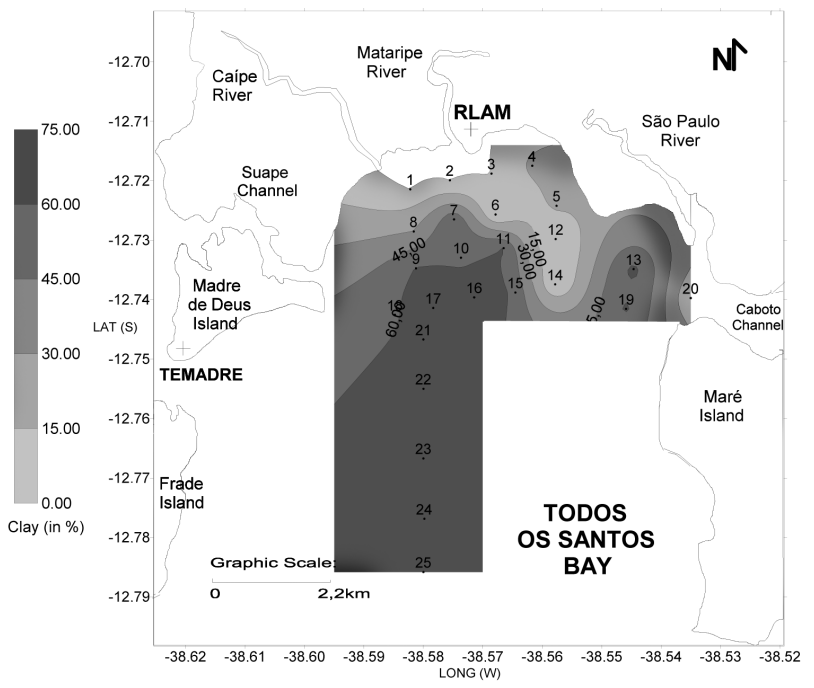

(d)

Figure 3. Sand contents (\%) in winter (a) and summer (b) and Clay contents (\%) in winter (c) and in summer (d) of sediment sampling stations.

$0.15 \%$. The stations with the highest percentages $(7,8,9,10,11,13,15,16,17,18,19,21,22,23,24$ and 25) are composed of lithoclastic sediments with very high mud contents (>87.9\%). Low contents were observed in the stations composed of coarser grain-size sediments (1, 2, 3 and 6).

The organic phosphorus in the winter of 2004 (Figure 7(a)) also showed an important spatial variation in the study region. The values varied between 0.1 and $15.9 \mu \mathrm{mol} \cdot \mathrm{g}^{-1}$, with an average of $7.4 \pm 4.8 \mu \mathrm{mol} \cdot \mathrm{g}^{-1}$. The stations which presented the highest contents of phosphorus, above $10.0 \mu \mathrm{mol} \cdot \mathrm{g}^{-1}$, were: $9,11,16,19,21,22,23$ and 24. In these samples the highest percentages of mud were observed ( $>96.2 \%)$ in sediments with low carbonate contents. The exceptions were stations 9 and 24 which presented contents over 30\% (lithobioclastics). Unlike the organic carbon and total nitrogen, higher values of organic phosphorus aren't located solely in the area close to the RLAM but are also present in the southern transect of the studied sampling net (stations 21 to 25). Lower contents $\left(<5.0 \mu \mathrm{mol} \cdot \mathrm{g}^{-1}\right)$ are observed in the two transects near the RLAM (stations 1 to 8 ) with the exception of station 7, in the stations rich in carbonate (12 and 14) and in the Caboto Channel (station 20). The summer 2005 values (Figure 7(b)) varied from 0.2 to $13.5 \mu \mathrm{mol} \cdot \mathrm{g}^{-1}$ with an average of $7.0 \pm 4.5 \mu \mathrm{mol} \cdot \mathrm{g}^{-1}$. The stations with a phosphorus values over $10.0 \mathrm{\mu mol} \cdot \mathrm{g}^{-1}$ were $10,11,15,17,18,19,22,23$ and 24 . Lower contents 


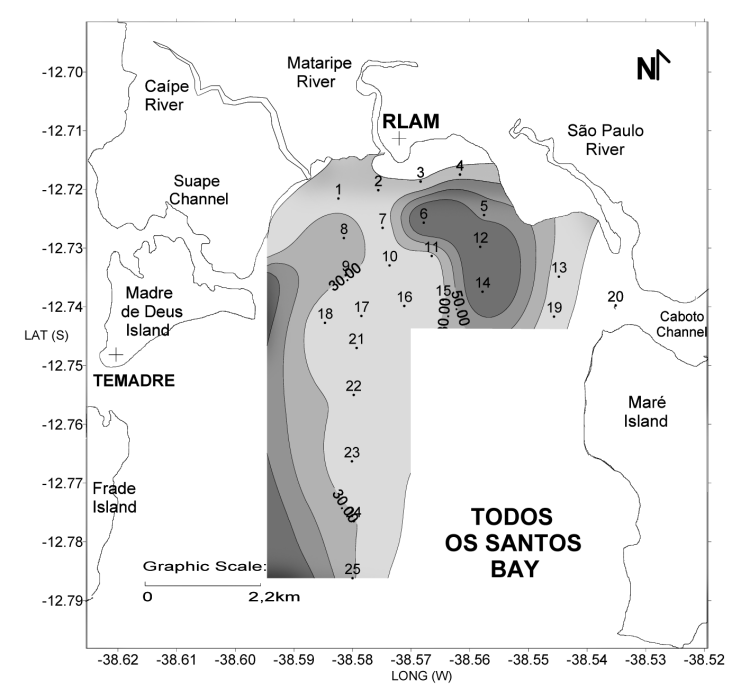

(a)

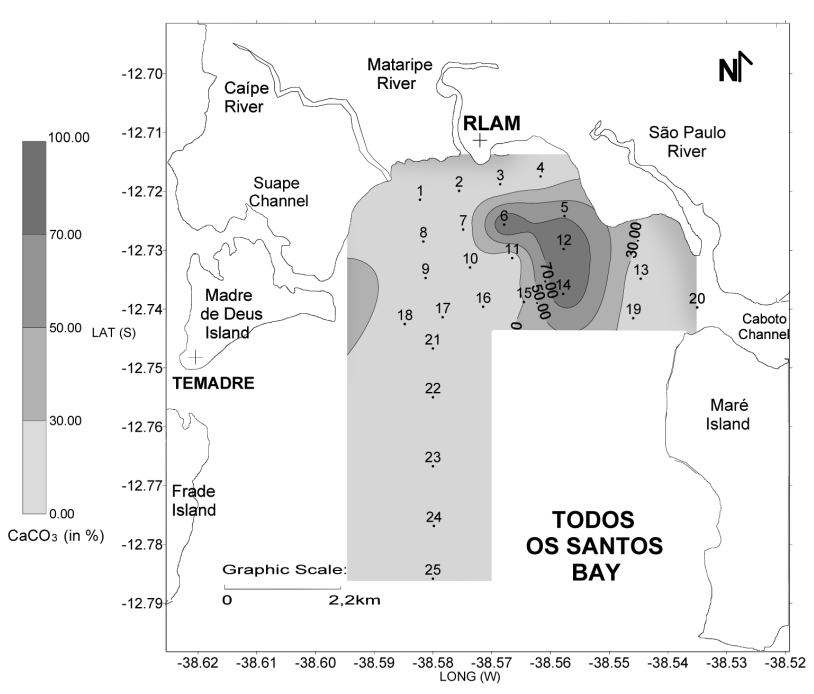

(b)

Figure 4. Calcium Carbonate contents (\%) of sediment sampling stations: winter (a) and summer (b).

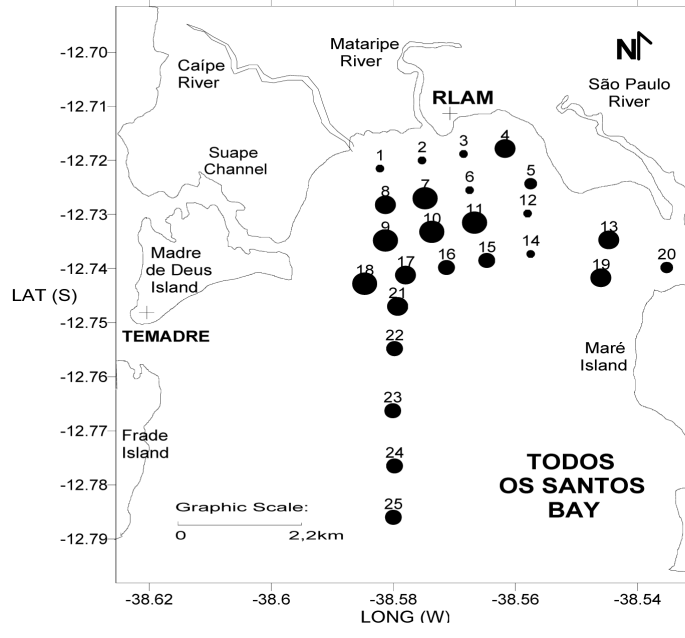

(a)

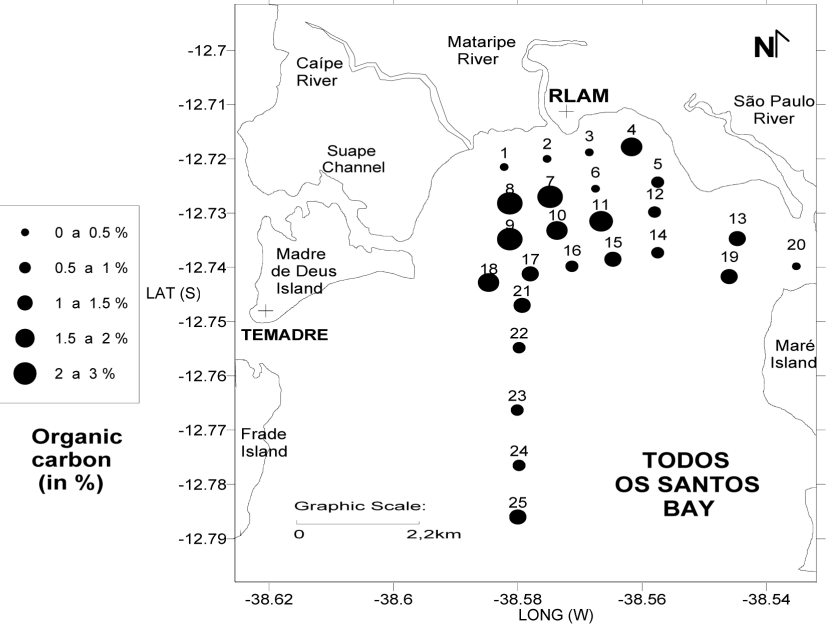

(b)

Figure 5. Organic Carbon contents (\%) of sediment sampling stations: winter (a) and summer (b).

of organic phosphate were observed in stations $1,2,3,4,6,8,12,14$ and 20. The two time periods exhibited similar distributions, with lower percentages in the stations near the coast and in the carbonate rich sediments. The higher percentages were found in the central and southern portions of the bays.

The $\mathrm{C} / \mathrm{N}$ ratio values range for the winter of 2004 (Figure 8(a)) varied from 5.3 to 28.8 and is related to the contributions of organic material of continental and marine origin with a predominance of values indicating mixed origin in $73 \%$ of the samples. Typically continental contributions $(\mathrm{C} / \mathrm{N}>20)$ are observed in stations 7,9 and 20 while organic matter of marine origin is identified in stations 1, 2, 6 and 12. For the summer 2005, sediment samples (Figure 8(b)), whose values varied from 5.2 to 23.6 a predominance of ratios indicating mixed origin was also observed ( $52 \%$ of the samples). Just as occurred for the winter samples, values above 20 are observed in the central and western portions of the bay (stations 7, 8 and 11), characterized by politic lithoclastic sediments, rich in organic matter. Low values are once again observed in station 2 (5.2), as well as in stations near the coast ( 1 and 3 ) and in station 12 , rich in $\mathrm{CaCO}_{3}$. Unlike what was observed in winter, the stations located in the external transects, towards the south $(16,21,22,23,24$ and 25), presented values of $\mathrm{C} / \mathrm{N}$ between 7.5 and 8.4, therefore near the value which indicated organic matter of marine origin (7.0) [9].

For the winter of 2004, the values of the C/P ratio (Figure 9(a)) varied from 20.4 to 176.6 with a predomin- 


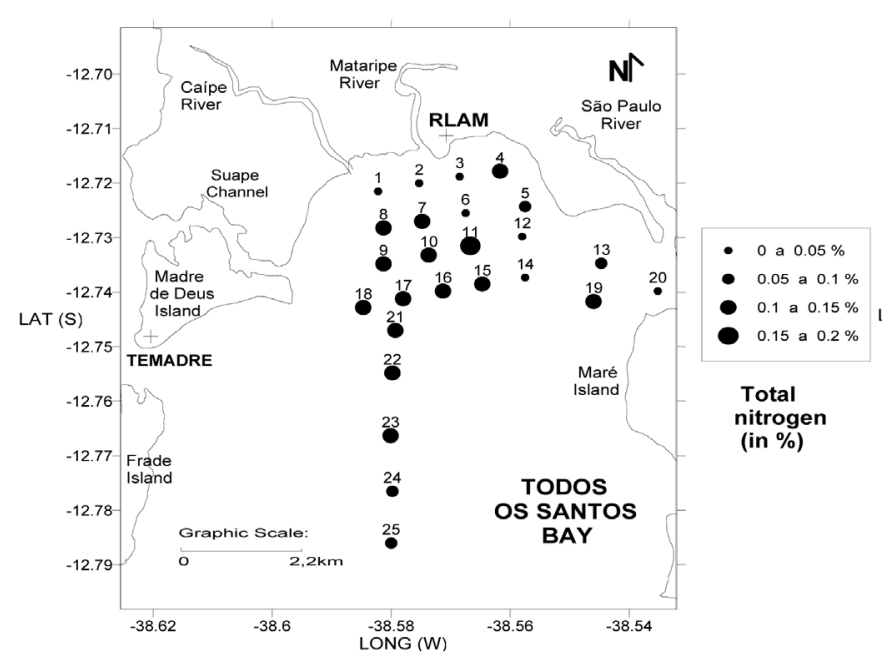

(a)

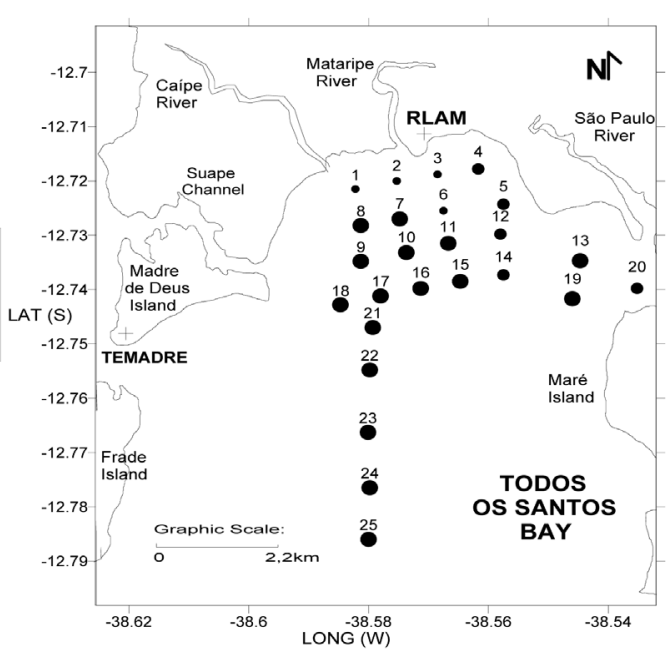

(b)

Figure 6. Total Nitrogen contents (\%) of sediment sampling stations: winter (a) and summer (b).

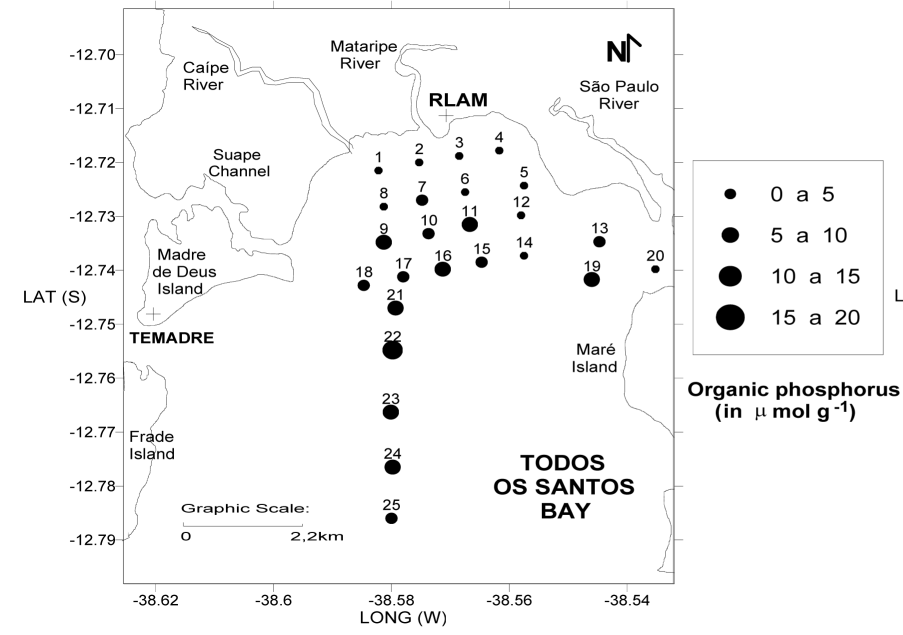

(a)

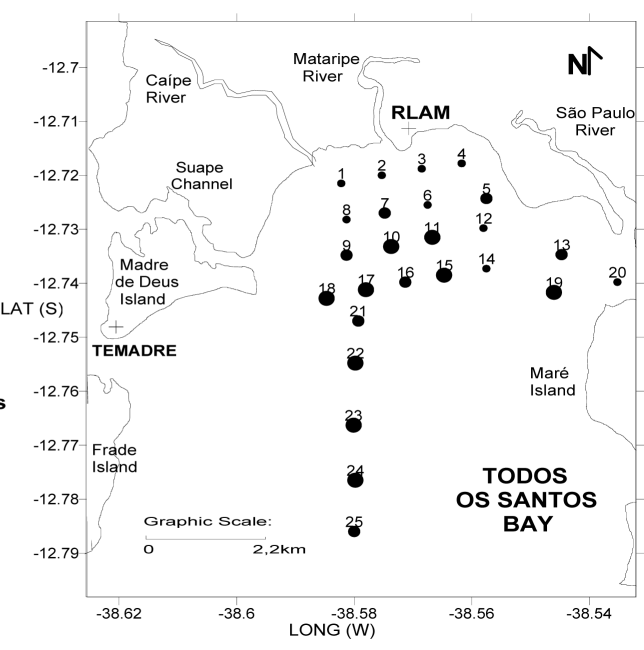

(b)

Figure 7. Organic Phosphorus in sediments: winter (a) and summer (b).

ance of values below 106 (72\% of the samples) which indicate organic matter of mixed origin, marine and bacterial. Values above the Redfield ratio (106) [12], which indicate a mixture of continental and marine sources [8], are observed in the RLAM adjacent area, near the coast (stations 1, 2, 3, 4 and 8) and in station 14 with high carbonate values. The remaining stations presented low C/P ratios $(<106)$, especially the ones located on the southern transect (stations 21 to 25) with values between 28.3 and 51.0. For the summer of 2005, the C/P ratio (Figure 9(b)) varied from 19.7 to 957.4 with values under 106 prevailing in $68.8 \%$ of the samples. The spatial distribution of the highest values (stations $1,2,3,4,7,8$ and 14) and lowest values (remaining stations) is similar to the winter distribution. For both time periods there is a decreasing gradient of $\mathrm{C} / \mathrm{P}$ ratios from the coast towards the more open areas of the bay. However, the set of values for both time periods are low, below 179.0 in $96 \%$ of the samples with the exception of station 3 and 6 in the summer which presented high and typically continental values: 661.5 and 957.4, respectively. The low values of the study area must be related to the input and adsorption of organic matter of bacterial origin in the sediments whose typical values vary from 7 to 80 (Gachter \& Mayer, 1993 apud [26]).

The N/P ratio values for the winter of 2004 (Figure 10(a)) varied from 2.2 to 30.6 with most values being below the Redfield ratio (16) [12], observed in 92\% of the samples. For the summer of 2005 (Figure 10(b)), the 


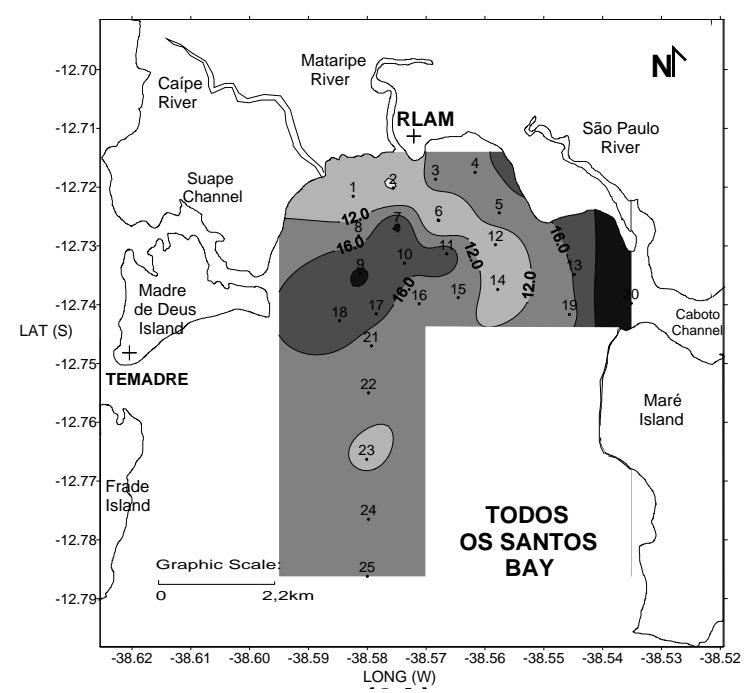

(a)

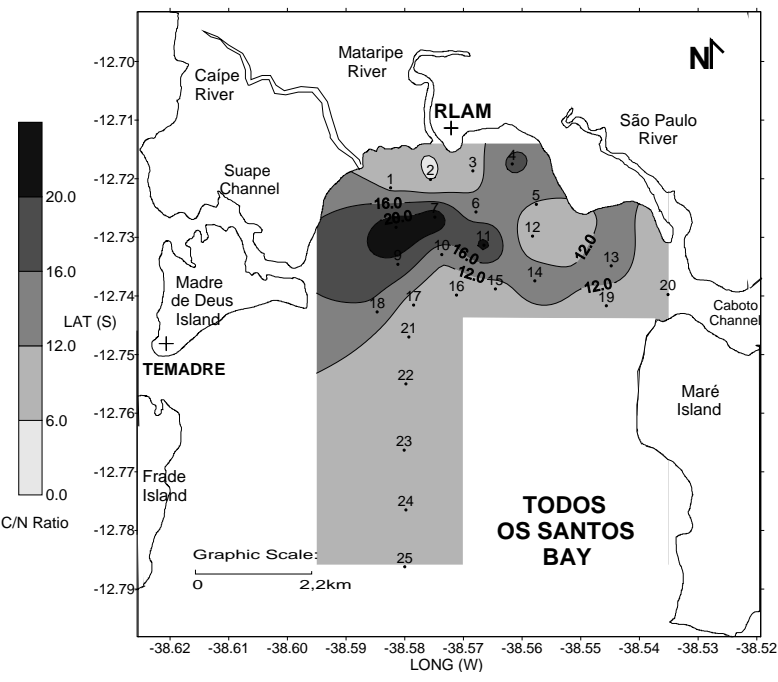

(b)

Figure 8. $\mathrm{C} / \mathrm{N}$ ratios in sediments sampling stations: winter (a) and summer (b).

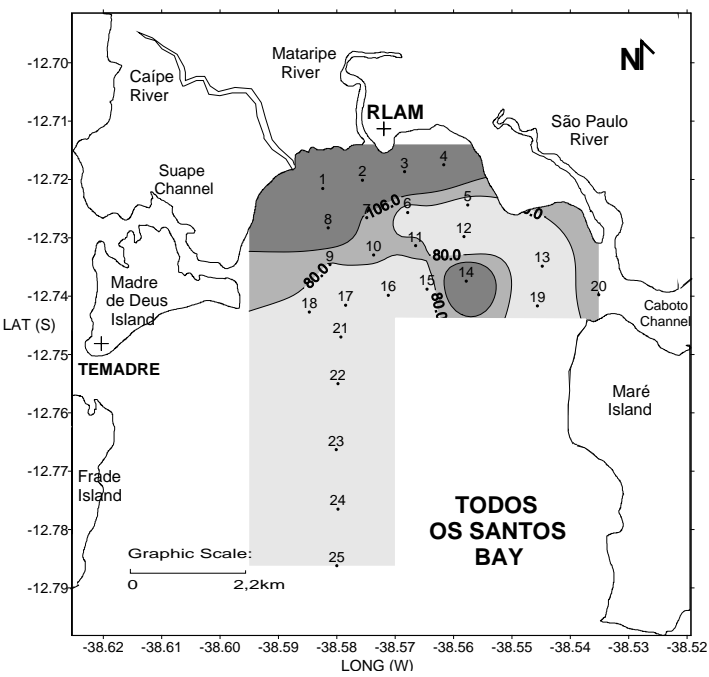

(a)

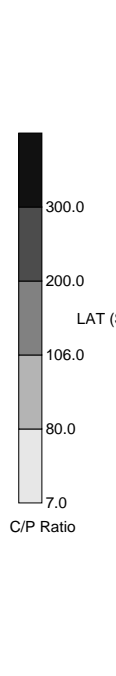

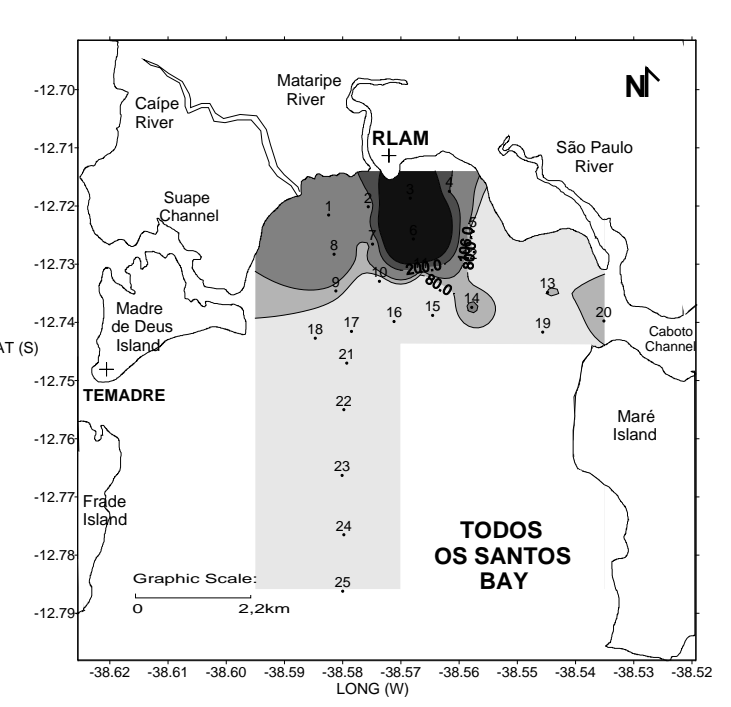

(b)

Figure 9. C/P ratios in sediments sampling stations: winter (a) and summer (b).

N/P ratios varied from 2.8 to 72.1, with values below 16 in $88 \%$ of the samples. The N/P ratio presents, for both studied periods, the same tendency of decreasing values from the coast towards the more external portions of the bay, observed for the $\mathrm{C} / \mathrm{P}$ ratio. The presence of spots of very high values in the area adjacent to the RLAM (stations 2, 3 and 6) is also noted, mainly during the summer.

In regards to Spearman linear correlation analysis for the sedimentary and geochemical parameters, found in Table 1, it is possible to state, for both time periods, that the most significant direct correlations occur among the components of organic matter (org $\mathrm{C}$, total $\mathrm{N}$ and org $\mathrm{P}$ ) and the pelits (silt and clay). The mean diameter values also present a strong positive correlation with the components of organic matter. Significant inverse correlations were observed between org $\mathrm{C}$., total $\mathrm{N}$ and org. $\mathrm{P}$ and the sands (below $r^{2}=-0.71$ ). The elements of organic matter presented strong correlation amongst themselves in the summer as well as in the winter. Some values stand out such as the ones observed between org $\mathrm{C}$ and total $\mathrm{N}$ in the winter $\left(r^{2}=0.91\right)$ and summer $\left(r^{2}=0.77\right)$ and the ones between total $\mathrm{N}$ and org $\mathrm{P}$ in the summer $\left(r^{2}=0.75\right)$.

Similar results were yielded by the statistical grouping analysis and the PCAs carried out separately for the

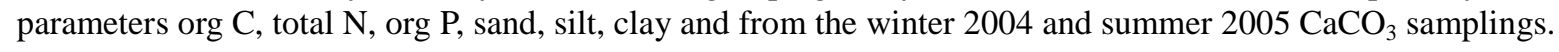




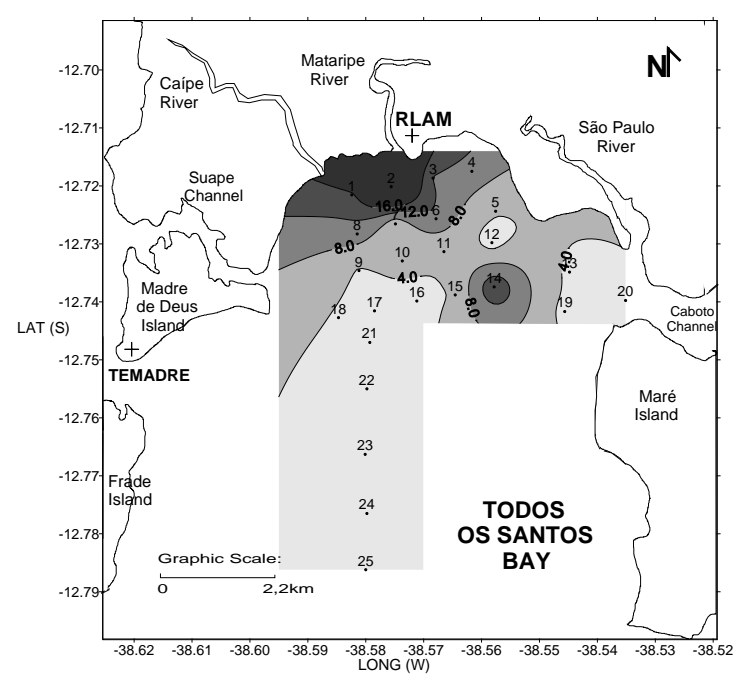

(a)

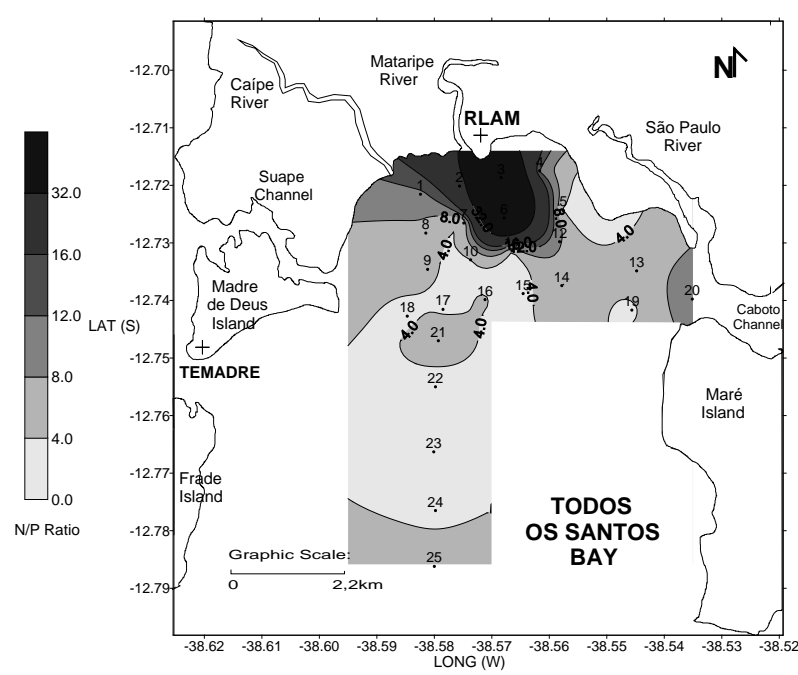

(b)

Figure 10. N/P ratios in sediments sampling stations: winter (a) and summer (b).

Table 1. Spearman linear correlation among geochemical and sedimentological parameters. Significant values are in bold.

\begin{tabular}{|c|c|c|c|c|c|c|c|c|c|c|c|c|}
\hline Parameters & C org & Total N & P org & $\%$ gravel & $\%$ sand & $\%$ silt & \% clay & $\% \mathrm{CaCO}_{3}$ & M. diam. & Sorting & Skewness & Kurtosis \\
\hline \multicolumn{13}{|c|}{ Winter 2004} \\
\hline C org & $X$ & $\mathrm{X}$ & $\mathrm{X}$ & $\mathrm{X}$ & $\mathrm{X}$ & $\mathrm{X}$ & $\mathrm{X}$ & $\mathrm{X}$ & $\mathrm{X}$ & $\mathrm{X}$ & $\mathrm{X}$ & $\mathrm{X}$ \\
\hline Total N & 0.91 & $\mathrm{X}$ & $X$ & $\mathrm{X}$ & $\mathrm{X}$ & $X$ & $\mathrm{X}$ & $\mathrm{X}$ & $\mathrm{X}$ & $\mathrm{X}$ & $\mathrm{X}$ & $\mathrm{X}$ \\
\hline P org & 0.52 & 0.57 & $\mathrm{X}$ & $\mathrm{X}$ & $\mathrm{X}$ & $\mathrm{X}$ & $\mathrm{X}$ & $\mathrm{X}$ & $\mathrm{X}$ & $\mathrm{X}$ & $\mathrm{X}$ & $\mathrm{X}$ \\
\hline \% gravel & -0.64 & -0.61 & -0.71 & $\mathrm{X}$ & $X$ & $\mathrm{X}$ & $X$ & $\mathrm{X}$ & $\mathrm{X}$ & $\mathrm{X}$ & $\mathrm{X}$ & $X$ \\
\hline$\%$ sand & -0.78 & -0.71 & -0.80 & 0.70 & $X$ & $\mathrm{X}$ & $\mathrm{X}$ & $\mathrm{X}$ & $\mathrm{X}$ & $\mathrm{X}$ & $\mathrm{X}$ & $\mathrm{X}$ \\
\hline$\%$ silt & 0.92 & 0.88 & 0.55 & -0.77 & -0.78 & $\mathrm{X}$ & $\mathrm{X}$ & $\mathrm{X}$ & $\mathrm{X}$ & $\mathrm{X}$ & $\mathrm{X}$ & $\mathrm{X}$ \\
\hline \% clay & 0.45 & 0.46 & 0.87 & -0.76 & -0.74 & 0.49 & $\mathrm{X}$ & $\mathrm{X}$ & $\mathrm{X}$ & $\mathrm{X}$ & $\mathrm{X}$ & $\mathrm{X}$ \\
\hline$\% \mathrm{CaCO}_{3}$ & -0.14 & -0.01 & -0.10 & 0.47 & 0.18 & -0.28 & -0.14 & $\mathrm{X}$ & $\mathrm{X}$ & $\mathrm{X}$ & $\mathrm{X}$ & $X$ \\
\hline Mean Diameter & 0.49 & 0.51 & 0.83 & -0.82 & -0.78 & 0.59 & 0.90 & -0.42 & $\mathrm{X}$ & $\mathrm{X}$ & $\mathrm{X}$ & $\mathrm{X}$ \\
\hline Sorting & 0.50 & 0.42 & 0.25 & -0.34 & -0.23 & 0.39 & 0.36 & 0.21 & 0.13 & $\mathrm{X}$ & $\mathrm{X}$ & $\mathrm{X}$ \\
\hline Skewness & -0.35 & -0.26 & -0.53 & 0.63 & 0.47 & -0.40 & -0.70 & 0.13 & -0.56 & -0.29 & $\mathrm{X}$ & $\mathrm{X}$ \\
\hline Kurtosis & -0.60 & -0.54 & -0.15 & 0.05 & 0.33 & -0.48 & -0.07 & -0.34 & 0.04 & -0.67 & 0.03 & $\mathrm{X}$ \\
\hline \multicolumn{13}{|c|}{ Summer 2005} \\
\hline C org & $\mathrm{X}$ & $\mathrm{X}$ & $\mathrm{X}$ & $\mathrm{X}$ & $\mathrm{X}$ & $\mathrm{X}$ & $\mathrm{X}$ & $\mathrm{X}$ & $\mathrm{X}$ & $\mathrm{X}$ & $\mathrm{X}$ & $\mathrm{X}$ \\
\hline Total N & 0.77 & $\mathrm{X}$ & $\mathrm{X}$ & $\mathrm{X}$ & $\mathrm{X}$ & $\mathrm{X}$ & $\mathrm{X}$ & $\mathrm{X}$ & $\mathrm{X}$ & $\mathrm{X}$ & $\mathrm{X}$ & $\mathrm{X}$ \\
\hline P org & 0.54 & 0.75 & $\mathrm{X}$ & $\mathrm{X}$ & $\mathrm{X}$ & $\mathrm{X}$ & $\mathrm{X}$ & $\mathrm{X}$ & $\mathrm{X}$ & $\mathrm{X}$ & $\mathrm{X}$ & $\mathrm{X}$ \\
\hline \% gravel & -0.46 & -0.62 & -0.60 & $\mathrm{X}$ & $\mathrm{X}$ & $\mathrm{X}$ & $X$ & $\mathrm{X}$ & $\mathrm{X}$ & $X$ & $\mathrm{X}$ & $\mathrm{X}$ \\
\hline$\%$ sand & -0.71 & -0.87 & -0.74 & 0.60 & $\mathrm{X}$ & $\mathrm{X}$ & $X$ & $X$ & $\mathrm{X}$ & $\mathrm{X}$ & $\mathrm{X}$ & $\mathrm{X}$ \\
\hline$\%$ silt & 0.86 & 0.78 & 0.68 & -0.71 & -0.72 & $\mathrm{X}$ & $\mathrm{X}$ & $\mathrm{X}$ & $\mathrm{X}$ & $\mathrm{X}$ & $\mathrm{X}$ & $\mathrm{X}$ \\
\hline \% clay & 0.41 & 0.68 & 0.69 & -0.66 & -0.76 & 0.47 & $\mathrm{X}$ & $\mathrm{X}$ & $\mathrm{X}$ & $\mathrm{X}$ & $\mathrm{X}$ & $\mathrm{X}$ \\
\hline$\% \mathrm{CaCO}_{3}$ & -0.07 & 0.06 & 0.22 & 0.31 & -0.09 & -0.05 & 0.06 & $\mathrm{X}$ & $\mathrm{X}$ & $\mathrm{X}$ & $\mathrm{X}$ & $\mathrm{X}$ \\
\hline Mean Diameter & 0.41 & 0.72 & 0.68 & -0.76 & -0.82 & 0.54 & 0.93 & -0.07 & $\mathrm{X}$ & $\mathrm{X}$ & $\mathrm{X}$ & $\mathrm{X}$ \\
\hline Sorting & 0.66 & 0.37 & 0.47 & -0.16 & -0.31 & 0.56 & 0.35 & 0.13 & 0.16 & $X$ & $\mathrm{X}$ & $\mathrm{X}$ \\
\hline Skewness & -0.41 & -0.61 & -0.68 & 0.65 & 0.51 & -0.53 & -0.62 & 0.12 & -0.54 & -0.34 & $\mathrm{X}$ & $\mathrm{X}$ \\
\hline Kurtosis & -0.45 & -0.17 & -0.08 & -0.11 & 0.08 & -0.37 & 0.21 & -0.39 & 0.35 & -0.45 & 0.04 & $\mathrm{X}$ \\
\hline
\end{tabular}


In the winter, as results of cluster analysis, three groups of stations with different faciological characteristics were observed. The first group is composed of stations 1, 2, 3, and 20, characterized by essentially sandy sediments with very low contents of organic matter. The second group is formed by stations 6,12 and 14, composed by coarse sediments, rich in calcium carbonate contents, which corresponds to the area under direct influence of the carbonate banks which present low values of org $\mathrm{C}$, total $\mathrm{N}$ and org P. The third group is composed of stations $4,7,9,10,11,13,15,16,17,18,19,21,22,23,24$ and 25 which present a predominance of peliticlithoclastic sediments (silt and clay) with high values of org C, total $\mathrm{N}$ and org P. A fourth group is formed by stations 5 and 8, composed of sediments with characteristics between groups 2 and 3, that is, with medium to high organic contents and calcium carbonate contents higher than in group 3.

For 2005 summer, the distribution of the groups was very similar to the winter distribution. Group 1, characterized by sandy sediments, with very low organic matter values, is also composed of stations 1, 2, 3 and 20. Group 2, formed by coarse carbonate rich sediments, is once again formed by stations 6,12 and 14, besides station 5, which presented similar characteristics for this time period. Group 3, characterized by mud sediments with high organic contents and low $\mathrm{CaCO}_{3}$ values is practically composed of the same stations as in winter: 7, 8, $9,10,11,13,15,16,17,18,19,21,22,23,24$ and 25 . The isolated station 4 , has similar characteristics to the winter group 4 , with intermediate values of organic matter, calcium carbonate and heterogeneous sediments.

Figure 11 illustrates the sedimentary facies distribution based on Cluster Analysis. Due to the relative data homogeneity in both studied periods, revealing slightly seasonal variations in sedimentary processes, this figure is represented by only 1 map.

\section{Discussion}

The area under influence of the RLAM presents low depths, up to 10 meters, with a smooth topography, except for the presence of a few carbonate reefs in its east portion. Reefs are also found in the southwestern portion of the sampled area, near the Suape Channel. The transect which extends itself to the mouth of the bay shows a predominance of mud and is part of the main area of deposition.

The fine and very fine, well sorted sands which dominate the area in its western coastal portion, suggest a low influence of current input to this region and bottom movements, which prevents the deposition of mud, transporting them to other portion of the area. These sediments are represented in Group 1 of the grouping analysis done for winter and summer. Deposits of well sorted fine sand indicate ancient depositional processes associated to relative fluctuations of the mean sea level [28]. In some samples (6 and 12) in the center-east portion of the

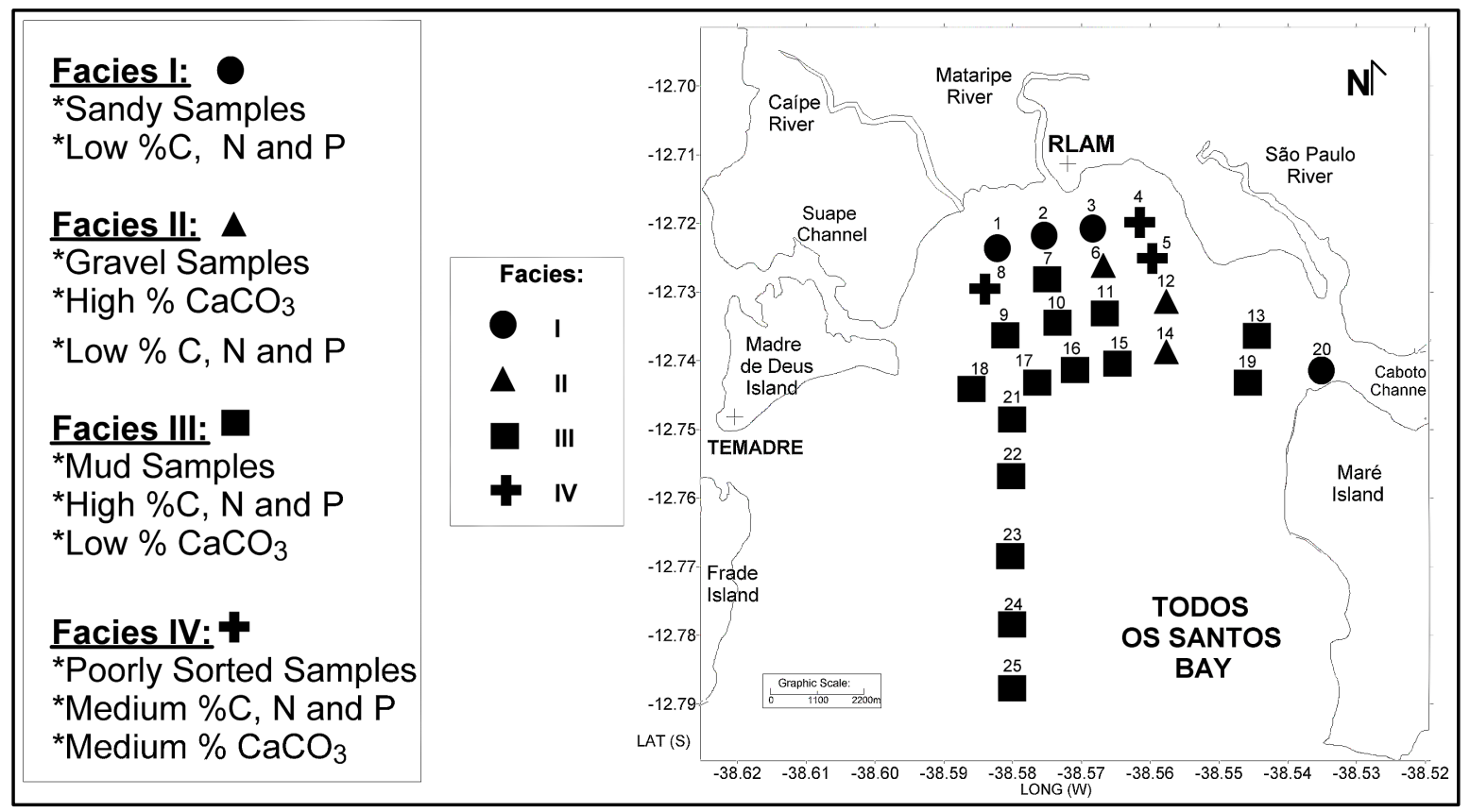

Figure 11. Sedimentary facies distribution for Todos os Santos Bay based on Cluster Analysis. 
area, the occurrence of this sand is associated to high levels of calcium carbonates and, not essentially, to the deposition of terrestrial sediments. The erosion of carbonate banks is the probably source of the material.

The silts and clays, associated to transport in suspension, are deposited to the east and in the central and southwest portion of the area, which is the main area of deposition currently, represented by group 3 in the grouping analysis, associated to the largest contributions of clay. This area, which is deeper than its surroundings, induces the retention of fine sediments. The samples are poorly sorted due to the contribution of finer grain-size classes, since the carbonate contents are not high. Samples 6, 12, and 14 however, present a high content of carbonate and are poorly and very poorly sorted, directly associated to the distribution of calcium carbonate in the different grain-size classes of the samples. They make up group 2 of the grouping analysis. Sample 4, in the northeast portion of the area, is poorly sorted due to its sediment size-classes heterogeneity which provide contributions to the different grain-size classes. This fact indicates the presence of a current source for the fine sediments and of relic sands in the area, that is, the occurrence of processes differentiated over time, possibly due to ancient sea regressions. In sample 5 , the greater presence of carbonates seems to be responsible for the heterogeneousness of the sample, also with current contribution of terrestrial fine sediments.

The modern deposition of fine sediments in the central portion of the area may occur as the coastal water leaves, carrying sediments in suspension from the Caípe and Mataripe rivers surpassing the region of sandy coastal deposits and depositing these sediments in low energy areas. The deposits, in the eastern portion, may be associated to the deviation of the Mataripe River flow which would be the main supplier of mud to the area. This situation is also found in previous sampling cruises (winter 2003 and summer 2004).

Taking into consideration the values of total organic carbon in the region near the RLAM, both time periods exhibited the highest contents in the central and eastern portions of the bay (stations 7, 8, 9, 10 and 11), with values over $2.0 \%$. Values under $2.0 \%$ are considered normal for coastal regions with high continental input, however, the maximum observed shows a richness of organic matter that is being currently deposited together with the particles of finer sediments. These particles, as the clays, have negative residual charges on their surfaces and attract the organic compounds forming sedimentary complexes which incorporate organic compounds to the bottom [29]. There are three main agents which regulate the deposition of organic carbon in the benthic environment, according to Reference [30]; the high production of organic carbon of marine origin, the increase in the preservation rate of organic carbon, and the contribution of organic matter of terrestrial origin by means of river and sewers, for example. The three rivers which discharge in the study area stretch out over mangrove areas. Therefore, there are probably great quantities of organic and inorganic material in suspension in the water column which could enter the bay by means of river transport. Reference [31], while studying the distribution of organic matter in the region's sediments, observed that high contents of total organic carbon were highly correlated to total nitrogen. The same is observed in the present study with significant correlations in the winter $\left(r^{2}=\right.$ $0.91)$, as well as in the summer $\left(r^{2}=0.77\right)$, which indicates the presence of common sources of material.

Overall, the values of organic carbon exhibited similar averages for both periods (Figure 5). Indeed, the organic carbon, although not very high in its contents $(<3.09 \%)$, shows a well marked distribution pattern which does not alternate between both periods. Values around 3.0\% were observed upstream of the Santos Estuarine System (São Paulo State, Brazil), a region which is subject to strong terrestrial and anthropic contribution [32] [33]. The values of total organic carbon in the Estuary and Santos Bay region varied from $0.09 \%$ to $5.78 \%$, with an average of $2.25 \%$ [32], and from $0.08 \%$ to $2.08 \%$ in sediments of the São Sebastião Channel (SP) [34]. In sediments of a dredging channel in India, specifically in Delhi's largest industrial zone on the Ganges, the values of total organic carbon varied from 2.32\% to 15\% [35]. In the case of the Guanabara Bay however, the values oscillated from $2.91 \%$ to $5.54 \%$ [36]. In the CONAMA resolution n ${ }^{\circ} 344 / 2004$ (source) [37], the values of total carbon may not exceed $10 \%$. Concentrations above this value may lead to environmental problems.

In regards to total nitrogen, high values $(>0.10 \%)$ were found for both periods (Figure 6), which reflects also a certain richness in organic material in differentiated areas of the Todos os Santos Bay, especially where the finer grain-size sediments prevailed. The northern region is very influenced by the presence of extensive mangrove areas, which undoubtedly represent a large contribution in nitrogen compounds. Levels of total nitrogen obtained in the sediments oscillated from $0 \%$ to $0.43 \%$, with an average of $0.17 \%$ in the Estuary and Santos Bay [33], from $0.01 \%$ to $0.36 \%$ in the superficial sediments of the Santos Bay [38] and from $0.00 \%$ to $0.23 \%$ in the São Sebastião Channel (SP) [34]. In the Guanabara Bay, the values of total nitrogen varied from $0.25 \%$ to $0.57 \%$ [36].

According to the CONAMA resolution $n^{\circ} 344 / 2004$ [37], values of total nitrogen above $0.48 \%$ or 4800 
$\mathrm{mg} \cdot \mathrm{Kg}^{-1}$ may cause damage to the environment. Overall, the values of NT are well below the limit established by the environmental legislation mentioned for dredged sediments, which should not be a reference for coastal zones exempt of anthropic impact. The total nitrogen also presented a strong correlation with org P contents, particularly, in the summer with $r^{2}=0.75$ (winter: $r^{2}=0.57$ ).

In regards to the organic phosphorus (Figure 7), on average the region presented a winter concentration of $0.023 \%\left(7.4 \mu \mathrm{mol} \cdot \mathrm{g}^{-1}\right)$ and $0.022 \%\left(7.0 \mu \mathrm{mol} \cdot \mathrm{g}^{-1}\right)$ in the summer, values which also did not vary seasonally. In the Ipanema submarine outfall region, the levels of organic phosphorus varied from $0.030 \%$ to $0.90 \%$ [39], while in the Guanabara Bay the values were between $0.019 \%$ and $0.042 \%$ [36]. In the Santos Estuary, the average values of organic phosphorous were of $5.06 \mu \mathrm{mol} \cdot \mathrm{g}^{-1}$ in the summer and $3.01 \mu \mathrm{mol} \cdot \mathrm{g}^{-1}$ in the winter of 2005 [40]. In places with low environmental impact such as the Cananéia region, located on the southern coast of São Paulo State, the levels of organic phosphorus varied from $0.002 \%$ to $0.046 \%$ with an average of $0.012 \%$ [ 41 ].

By what has been stated in the previous paragraphs, it becomes clear that significant seasonal variations do not occur in the contents and spatial distributions of the three organic matter parameters studied. The levels of org C, total N and org P are very similar between the winter of 2004 and summer of 2005 in the region. While the presence of organic material is detected by the signs of phosphorus, organic carbon and total nitrogen, the values of the C/N, C/P and N/P ratios (see Figures 8-10) show the marine, terrestrial and bacterial influences on the sediments.

In the present study, the $\mathrm{C} / \mathrm{N}$ ratio indicated a mixed influence of the organic matter with relatively variable marine and continental contributions in the studied spots. The same was found in the studies of Reference [31]. This variability in the $\mathrm{C} / \mathrm{N}$ ratio is common in sheltered coastal environments with shallow depths, leading to the mixed nature of the organic matter [42]. Reference [43] also observed the predominance of C/N ratios which indicate mixed origin in $73 \%$ of the sediment samples analyzed for the Cananéia-Iguape estuarine-lagoonal system (São Paulo State, Brazil). Studies carried out in sediments of the Santos estuarine system, by means of C/N ratios, showed contributions of organic material of continental as well as marine origin [33]. The spatial distribution of the $\mathrm{C} / \mathrm{P}$ and N/P ratio values, on the other hand, indicated a more fixed pattern, with a tendency of decreasing in organic material of continental origin, from the immediate adjacency of the RLAM, towards the more external portions of the bay.

Even though this distribution pattern is not as clear in regards to the $\mathrm{C} / \mathrm{N}$ ratio, the $\mathrm{C} / \mathrm{N}$ ratios in the central and southwest portion of the bay (stations 7, 8, 9, 10 and 11) were above 20 in both time periods. Reference [44] indicate that $\mathrm{C} / \mathrm{N}$ values above 24 may be used as large estimates of continental influence on organic matter in the sediment. In the study area the highest concentrations of organic matter were observed in lithoclastic sediments, especially pelitic sediments. These values and the concentration of fine sediments and organic matter indicate a modern process of continental input of material which is accumulating in the area's sediments and comes from the region's rivers and mangroves. However, if the sources of organic material were purely natural, higher values would be expected in the external and deeper stations (stations 16, 17, 18, 21, 22, 23, 24 and 25) that presented clay concentrations up to $30 \%$ higher than the coastal stations. This does not happen because of the current input of anthropogenic sources of organic matter whose main origin seems to be effluents rich in petroleum hydrocarbons (PAHs), derived from the RLAM. Indeed, [45], by analyzing the sediments of this portion of the bay, encountered PAH contents above $500 \mathrm{ng} \cdot \mathrm{g}^{-1}$ indicating highly contaminated sediments (Notar et al., 2001 apud [45]). The C/S ratios observed by these same authors, which varied from 1.5 to 13.6, showed a general tendency for the region of oxidating conditions on the bottom with the exception of this area (stations 7 to 11 ) and the area adjacent to the refinery (stations $2,3,4$ and 6) where the sulphur contents were high $(>1.0 \%)$. Reference [34] also observed low values of the C/S ratio and high values of sulphur in the region adjacent to the PETROBRÁS petroleum terminal (DTCS) in the São Sebastião Channel (São Paulo State, Brazil). Reference [33] observed a mean C/S ratio of 1.86 in the Santos Estuary (São Paulo State, Brazil) with a minimum of 0.09 in this estuary main channel indicating a strong reduction (anoxic) characteristic in the internal portion of the estuary where there is a larger amount of pelitic sediments and the presence of an important industrial pole. Reference [46] states that one of the sources of sulphur to marine environments is from anthropogenic nature, represented by the petroleum impact.Reference [31] also obtained, for the study area, results which indicate a high degree of anthropogenic contribution related to the residues of degraded petroleum. These authors observed still, very high contents of non-degraded petroleum (the highest of this study) in the sediments adjacent to the RLAM (stations 3, 4 and 6) which may have reflected on the high values of the $\mathrm{C} / \mathrm{P}$ and N/P ratios presented by these stations in the summer of 2005. 


\section{Conclusions}

One may conclude, for the area under influence of the RLAM, that the highest contents of carbonates are derived from the presence of reefs and limestone banks which are fragmented originating the bioclastic contribution to the sediments. The rivers in the adjacent coastal area are responsible for the modern input of mud which are transported in suspension and deposited in lower energy spots. These places are, therefore, propitious to the retention of organic and inorganic chemical elements. The sands may be present due to the bioclastic contribution. The terrigenous contributions, however, are concentrated in the fractions of fine and very fine sand and are very well sorted. They serve as indicators of previous processes associated to Quaternary fluctuations of the sea level. They would correspond to ancient sandy plains in marine regressions, reworked by subsequent transgressions. The significant presence of muds in the region under influence of the RLAM indicates that there is a process of current deposition of fine sediments, that is, the material that enters the area has a tendency of remaining there, while the area itself is likely to retain contaminants and pollutants.

The contents of org $\mathrm{C}$ and org $\mathrm{P}$ present in the study area are similar to the ones observed in other sheltered tropical coastal regions subject to contributions of human activities in addition to natural contributions. In the case of total $\mathrm{N}$, relatively high contents were found $(>0.10 \%)$ in both time periods.

There are no significant seasonal variations in the contents and spatial distributions of the three organic matter parameters studied. The contents of org C, total N and org P were very similar between the winter of 2004 and summer of 2005.

The stations characterized by high levels of org $\mathrm{C}$, total $\mathrm{N}$ and org $\mathrm{P}$ (Group 3 of the grouping analysis) are those which present high contents of silt and clay, that is, the influence of the fine fraction is directly on the values of MO. Significant direct linear correlations were observed among the organic matter components and the fine sediments, as well as a strong inverse correlation with the sands $\left(<r^{2}=-0.71\right)$.

The association of the MO with the fine fraction of the sediment indicates that the hydrodynamics and, in its turn, the topography to which it conforms, as well as the contributions of the biotic material which is disposed in the hydric system, are determinants for the geographic distribution of the MO levels in the study region. The variation of the terrestrial inputs, whether they are natural or due to human activities, influences the spatial distribution of the MO contents, especially in the area on the coast adjacent to the RLAM.

Overall, the carbon and nitrogen values do not surpass the limits defined by the CONAMA resolution no. $344 / 2004$ for dredged sediments [37]. However, this reference is not adequate for our motive of study since we are dealing with a bay whose depuration capacity differs from dredged channels. Therefore, these and the other studied parameters (organic $\mathrm{P}$ and elementary $\mathrm{C} / \mathrm{N}, \mathrm{C} / \mathrm{P}$ and N/P ratios) evidence a richness associated to the presence of organic matter in some spots of the Todos os Santos Bay, which may contribute to the increase in concentration of a few contaminants which have an affinity to organic matter, such as the PAHs derived from the RLAM. The correlation among the organic matter components and some contaminants is known, especially in risk zones. Such is the case in the Todos os Santos Bay where the contributions composed of components derived from anthropic activities are common and constant. Finally, the coupling of sediment and geochemical information constitutes an excellent tool for the evaluation and diagnosis of the biogeochemical quality of coastal systems.

\section{Acknowledgements}

The authors thank the PROMARLAM Project (PETROBRAS) for the incentive in disclosing the obtained data. Also, we would like to thank all the crew of technicians and trainees involved in the collecting and acquisition of data as well as to the assessors of the Project for the pertinent observations.

\section{References}

[1] Boggs, S. (1995) Principles of Sedimentology and Stratigraphy. 2nd Edition, Prentice Hall, New Jersey, 765 p.

[2] Pettijohn, F.J. (1975) Sedimentary Rocks. 2nd Edition, Harper and Row Publishers, New York, 628 p.

[3] Suguio, K. (2003) Geologia Sedimentar. 1st Edition, Edgard Blücher, São Paulo, 400 p.

[4] Förstner, U. (1990) Inorganic Chemistry and Elemental Speciation. In: Baudo, R., Giesy, J.P. and Muntau, H., Eds., Sediments: Chemistry and Toxicity of In-Place Pollutants, Lewis Publishers, Boca Raton, 61-105.

[5] Lick, W. (1986) Modeling the Transport of Fine-Grained Sediments in Aquatic Systems. Science Total Environment, 


\section{5, 219-228. http://dx.doi.org/10.1016/0048-9697(86)90181-6}

[6] Ziegler, C.K., Tsai, C.H. and Lick, W. (1988) Transport of Sediments in the Venice Lagoon. Proceedings of 3rd International Conference on Environmental Contamination, Venice, September 1988, 336-338.

[7] Reading, H.G. and Collinson, J.D. (1996) Clastic Coasts. In: Reading, H.G., Ed., Sedimentary Environments: Processes, Facies and Stratigraphy, 3rd Edition, Blackwell Science, London, 688 p.

[8] Ruttenberg, K.C. and Goñi, M.A. (1997) Phosphorus Distribution, C:N:P Ratios, and $d^{13} C_{o c}$ in Artic, Temperate and Tropical Coastal Sediments: Tools for Characterizing Bulk Sedimentary Organic Matter. Marine Geology, 139, 123145. http://dx.doi.org/10.1016/S0025-3227(96)00107-7

[9] Saito, Y., Nishimura, A. and Matsumoto, E. (1989) Transgressive and Sheet Covering the Shelf and Upper Slope off Sendai, Northeastern Japan. Marine Geology, 89, 245-258. http://dx.doi.org/10.1016/0025-3227(89)90078-9

[10] Jennerjahn, T.C., Ittekkot, V., Klöpper, S., Adi, S., Nugroho, S. P., Sudiana, N., Yusmal, A., Prihartanto and GayeHaake, B. (2004) Biogeochemistry of a Tropical River Affected by Human Activities in Its Catchment: Barntas River Estuary and Coastal Waters of Madura Strait, Java, Indonesia. Estuarine, Coastal and Shelf Science, 60, 503-514. http://dx.doi.org/10.1016/j.ecss.2004.02.008

[11] Lamb, A.L., Graham, P.W. and Leng, M.J. (2006) A Review of Coastal Palaeoclimate and Relative Sea-Level Reconstructions Using $\delta^{13} \mathrm{C}$ and $\mathrm{C} / \mathrm{N}$ Ratios in Organic Matter. Earth-Science Reviews, 75, 29-57. http://dx.doi.org/10.1016/j.earscirev.2005.10.003

[12] Redfield, A.C., Ketchum, B.H. and Richards, F.A. (1963) The Influence of Organisms on the Composition of the Sea Water. In: Hill, M.N., Ed., The Sea, Vol. 2, Interscience Publishers, New York, 26-77.

[13] GDB (Bahia State Government) (2000) Saneamento ambiental da Baía de Todos os Santos (BTS). Diagnóstico da qualidade das águas da BTS (Estudos preliminares, fontes de poluição, legislação e metodologia). Report, Salvador.

[14] Ponce, V.R. and Correa, C.I. (1980) Contribuição à sedimentologia da Baía de Todos os Santos-Parte Leste. Anais Hidrográficos, 37, 113-139.

[15] Tavares, T.M., Roch, V.C., Porte, C., Barceló, D. and Albaigés, J. (1988) Application of the Mussel Watch Concept in Studies of Hydrocarbons, PCBs and DDT in Brazilian Bay of Todos os Santos (Bahia). Marine Pollution Bulletin, 19, 575-578. http://dx.doi.org/10.1016/0025-326X(88)90022-7

[16] IBGE (2010) Anuário estatístico do Brasil. Instituto Brasileiro de Geografia e Estatística, São Paulo, 520 p.

[17] Müller, G. (1967) Methods in Sedimentary Petrography (Part I). Hafner Publishing Co., New York, 283 p.

[18] Ingram, R.L. (1971) Sieve Analysis. In: Carver, R.E., Ed., Procedures in Sedimentary Petrology, Wiley Interscience, New York, 49-69.

[19] Larssoneur, C., Bouysse, P. and Aufret, J.P. (1982) The Superficial Sediments of the English Channel and Its Western Approach. Sedimentology, 29, 851-864. http://dx.doi.org/10.1111/j.1365-3091.1982.tb00088.x

[20] Gaudette, H.E., Flight, W.R., Towner, L. and Folger, D.W. (1994) An Inexpensive Triation Method for Determination of Organic Carbon in Recent Sediments. Journal of Sedimentary Petrology, 44, 249-253.

[21] Aspila, K.I.H., Agemian, A.S. and Chau, Y. (1976) A Semi-Automatic Method for Determination of Inorganic, Organic and Total Phosphate in Sediments. Analyst, 101, 187-197. http://dx.doi.org/10.1039/an9760100187

[22] Grasshoff, K., Ehrhardt, M. and Kremling, K. (1983) Methods of Seawater Analysis. 2nd Edition, Verlag Chemie Weinhein, New York, 419 p.

[23] Folk, R.L. and Ward, W.C. (1957) Brazos River Bar: Study of the Significance of Grain Size Parameters. Journal of Sedimentary Petrology, 27, 3-27. http://dx.doi.org/10.1306/74D70646-2B21-11D7-8648000102C1865D

[24] Shepard, F.P. (1954) Nomenclature Based on Sand-Silt-Clay Ratios. Journal of Sedimentary Petrology, 24, $151-158$.

[25] Zar, J.H. (1999) Biostatistical Analysis. 4th Edition, Prentice Hall, Englewood Cliffs, 663 p.

[26] Suguio, K. (1973) Introdução à Sedimentologia. Edgard Blücher/EDUSP, São Paulo, 317 p.

[27] Calvo, C., Grasso, M. and Gardenghi, G. (1991) Organic Carbon and Nitrogen in Sediments and Resuspended Sediments of Venice Lagoon: Relationships with PCB Contamination. Marine Pollution Bulletin, 22, 543-547. http://dx.doi.org/10.1016/0025-326X(91)90893-W

[28] Swift, D.J.P., Oertel, G.F., Tillman, R.W. and Thorne, J.A., Eds. (1991) Shelf Sands and Sandstone Bodies: Geometry, Facies and Sequence Stratigraphy. John Wiley \& Sons, New Jersey, 532 p.

[29] Sharp, J.H. (1973) Size Classes of Organic Carbon in Seawater. Limnology and Oceanogaphy, 18, 441-447. http://dx.doi.org/10.4319/lo.1973.18.3.0441

[30] Stein, R. (1991) Accumulation of Organic Matter in Marine Sediments. Results from Deep Sea Drilling Project/Ocean Drilling Program. In: Bhattacharji, S., Friedman, G.M., Neugebauer, H.J., Seilacher, A., Eds., Lectures Notes in Earth Sciences, Vol. 34, Springer, Berlin, 217 p. 
[31] Venturini, N., Tommasi, L.R., Bícego, M.C. and Martins, C.C. (2004) Characterization of the Benthic Environment of a Coastal Area Adjacent to an Oil Refinery, Todos os Santos Bay (NE-Brazil). Brazilian Journal of Oceanography, 52, 39-50. http://dx.doi.org/10.1590/S1679-87592004000200004

[32] Siqueira, G.W. (2003) Estudo dos teores de metais pesados e outros elementos em sedimentos superficiais do Sistema Estuarino de Santos (São Paulo) e da Plataforma Continental do Amazonas (Margem Continental Norte). Ph.D. Thesis, University of São Paulo, São Paulo, 326 p.

[33] Siqueira, G.W., Braga, E.S., Mahiques, M.M. and Aprile, F.M. (2006) Determinação da matéria orgânica e razões C/N e C/S em sedimentos de fundo do estuário de Santos-SP/Brasil. Arquivos de Ciências do Mar, 39, 18-27.

[34] Barcellos, R.L. and Furtado, V.V. (2006) Organic Matter Contents and Modern Sedimentation at São Sebastião Channel, São Paulo State, South-Eastern, Brazil. Journal of Coastal Research, 39, 1073-1077.

[35] Moturi, M.C.Z., Rawat, M. and Subramanian, V. (2005) Distribution and Partitioning of Phosphorus in Solid Waste and Sediments from Drainage Canals in the Industrial Belt of Delhi, India. Chemosphere, 60, 237-244. http://dx.doi.org/10.1016/j.chemosphere.2004.11.032

[36] Carrera, R.S. (2000) Investigação sobre o acréscimo da estocagem de carbono em ambientes fertilizados pela ação antropogênica: A Baía de Guanabara como modelo. Ph.D. Thesis, Rio de Janeiro Catholic University (PUC-RJ), Rio de Janeiro.

[37] CONAMA (2004) n³44/2004. http://www.mma.gov.br/port/conama/res/res04/res34404.xml

[38] Fukumoto, M. (2003) Caracterização da sedimentação atual e reconstituição da história deposicional recente da Baía de Santos, a partir das características composicionais e isotópicas da matéria orgânica. Master’s Thesis, University of São Paulo, São Paulo, 96 p.

[39] Carrera, R.S. and Wagener, L.R. (1998) Speciation of Sewage Derived Phosphorus in Coastal Sediments form Rio de Janeiro, Brazil. Marine Pollution Bulletin, 36, 818-827. http://dx.doi.org/10.1016/S0025-326X(98)00062-9

[40] Berbel, G.B.B. and Braga, E.S. (2008) Variação sazonal (inverno e verão de 2005) das especiações de fósforo dissolvido e fósforo sedimentar em Santos e suas inter-relações com parâmetros físicos e químicos. Oceanografia e Mudanças Globais-III Simpósio Brasileiro de Oceanografia, Vol. 1, São Paulo, Ed. USP, 583-597.

[41] Barcellos, R.L., Berbel, G.B.B., Braga, E.S. and Furtado, V.V. (2005) Distribuição e características do fósforo sedimentar no sistema estuarino lagunar de Cananéia-Iguape, Estado de São Paulo, Brasil. Geochimica Brasiliensis, 19, 22-36.

[42] Bordovskiy, O.K. (1965) Accumulation of Organic Matter in Bottom Sediments. Marine Geology, 3, 33-82. http://dx.doi.org/10.1016/0025-3227(65)90004-6

[43] Barcellos, R.L. (2005) Processo Sedimentar Atual e a Distribuição da Matéria Orgânica Sedimentar no Sistema Estuarino-Lagunar de Cananéia—Iguape (SP). Ph.D. Thesis, Universityof São Paulo, São Paulo, 187 p.

[44] de Mahiques, M.M., Mishima, Y. and Rodrigues, M. (1999) Characteristics of the Sedimentary Organic Matter on the Inner and Middle Continental Shelf between Guanabara Bay and São Francisco do Sul, Southeastern Brazilian Margin. Continental Shelf Research, 19, 775-798. http://dx.doi.org/10.1016/S0278-4343(98)00105-8

[45] Venturini, N. and Tommasi, L.R. (2004) Polycyclic Aromatic Hydrocarbons and Changes in the Throphic Structure of Polychaete Assemblages in Sediments of Todos os Santos Bay, Northeastern, Brazil. Brazilian Journal of Oceanography, 52, 39-50.

[46] Berner, R.A. (1984) Sedimentary Pirite Formation: An Update. Geochmicaet Cosmochimica Acta, 4, 605-615. http://dx.doi.org/10.1016/0016-7037(84)90089-9 
Scientific Research Publishing (SCIRP) is one of the largest Open Access journal publishers. It is currently publishing more than 200 open access, online, peer-reviewed journals covering a wide range of academic disciplines. SCIRP serves the worldwide academic communities and contributes to the progress and application of science with its publication.

Other selected journals from SCIRP are listed as below. Submit your manuscript to us via either submit@scirp.org or Online Submission Portal.
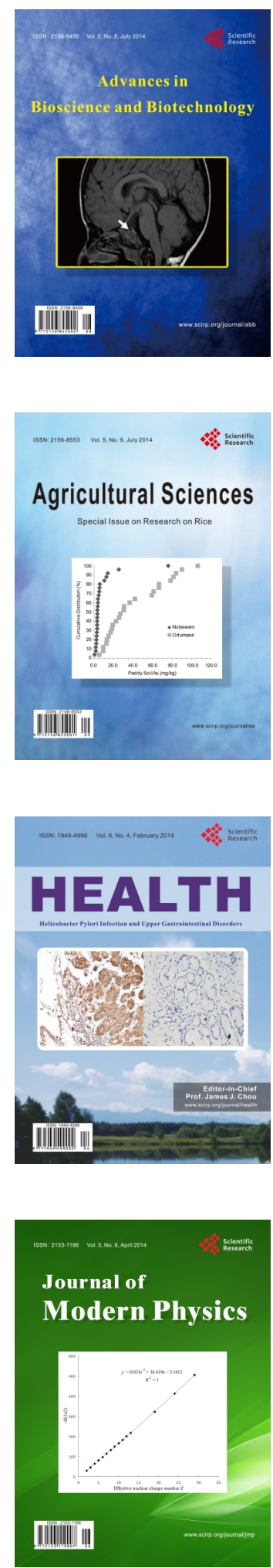
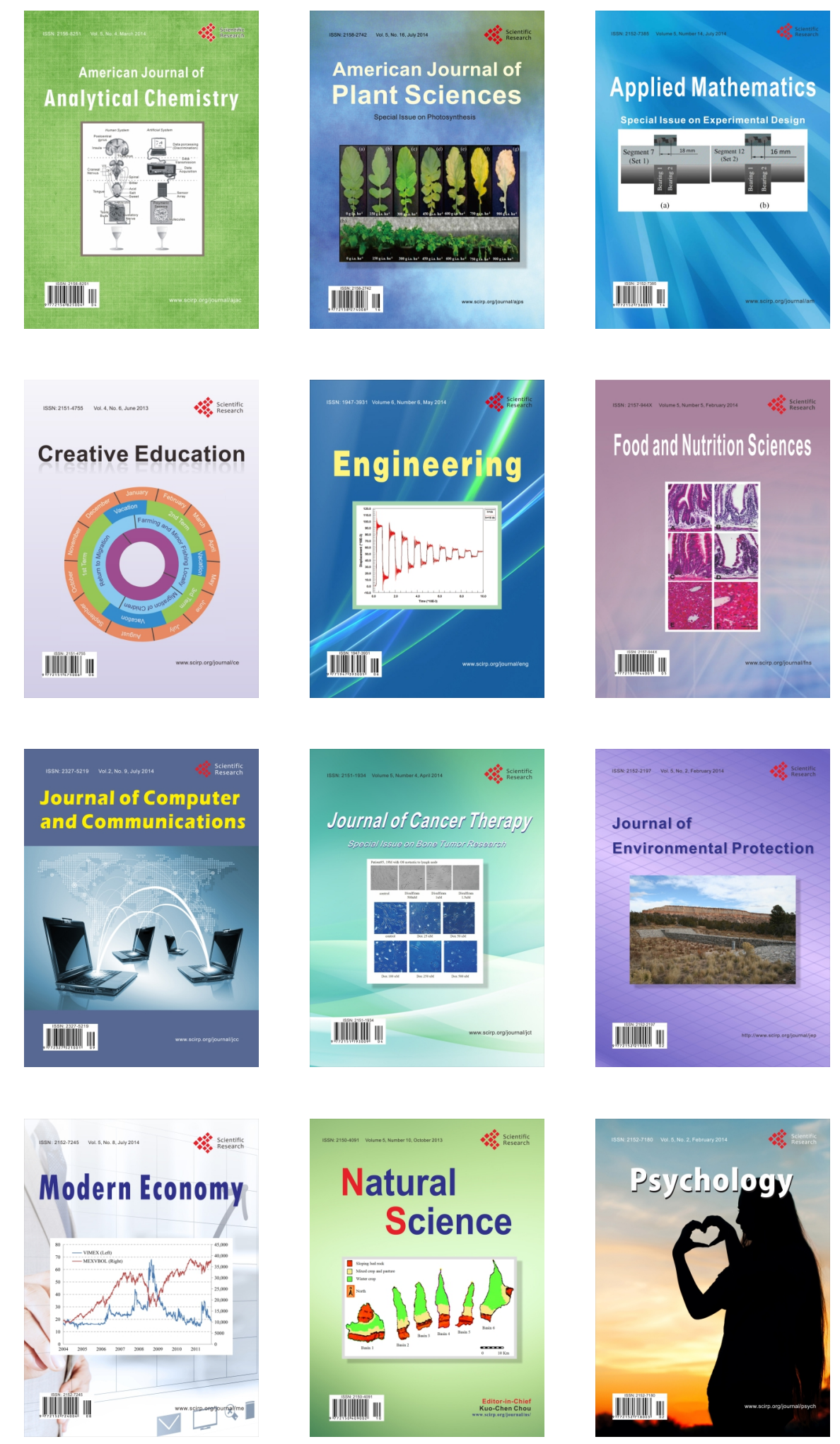